\title{
Microstructures in Metasedimentary Rocks from the Neoproterozoic Bonahaven Formation, Scotland: Microconcretions, Impact Spherules, or Microfossils?
}

\section{Citation}

Anderson, Ross P., Ian J. Fairchild, Nicholas J. Tosca, and Andrew H. Knoll. 2013.

Microstructures in Metasedimentary Rocks from the Neoproterozoic Bonahaven Formation, Scotland: Microconcretions, Impact Spherules, or Microfossils? Precambrian Research 233: 5972.

\section{Published Version}

doi:10.1016/j.precamres.2013.04.016

\section{Permanent link}

http://nrs.harvard.edu/urn-3:HUL.InstRepos:12332509

\section{Terms of Use}

This article was downloaded from Harvard University's DASH repository, and is made available under the terms and conditions applicable to Open Access Policy Articles, as set forth at http:// nrs.harvard.edu/urn-3:HUL.InstRepos:dash.current.terms-of-use\#OAP

\section{Share Your Story}

The Harvard community has made this article openly available.

Please share how this access benefits you. Submit a story. 


\section{TITLE}

2 Microstructures in metasedimentary rocks from the Neoproterozoic Bonahaven Formation,

3 Scotland: Microconcretions, impact spherules, or microfossils?

\section{AUTHORS}

5 Ross P. Anderson*1 ${ }^{1}$, Ian J. Fairchild ${ }^{2}$, Nicholas J. Tosca ${ }^{3}$, and Andrew H. Knoll ${ }^{4}$

$6 \quad *$ corresponding author

7 AFFILIATIONS

$8{ }^{1}$ Department of Earth and Planetary Sciences, Harvard University, 20 Oxford Street, Cambridge, 9 MA, 02138 USA. Present address: Department of Geology and Geophysics, Yale University, 10210 Whitney Avenue, New Haven, CT, 06511, USA.

11 Email: ross.anderson@yale.edu Telephone: +441159830786 or +16178003291

$12{ }^{2}$ School of Geography, Earth and Environmental Sciences, University of Birmingham, 13 Edgbaston, Birmingham, B15 2TT, UK.

14 Email: i.j.fairchild@,bham.ac.uk

$15{ }^{3}$ Department of Earth Sciences, Irvine Building, University of St Andrews, St Andrews, Fife, 16 KY16 9AL, UK.

17 Email: njt6@st-andrews.ac.uk

$18{ }^{4}$ Department of Organismic and Evolutionary Biology, Harvard University, 26 Oxford Street, 19 Cambridge, MA, 02138, USA.

20 Email: aknoll@,oeb.harvard.edu

\section{ABSTRACT}

22 Microscopic spherules in relatively undeformed mudstones of the Neoproterozoic Bonahaven 23 Formation, Islay, Scotland, are differentiated from their matrix by a sharp micron-scale, 24 smoothly rounded boundary. These elongate spherules were earlier interpreted as hollow bodies filled penecontemporaneously by glauconite and subsequently metamorphosed to phengite, but their origin remains a matter of debate. Spherules observed in thin section are predominantly

27 rounded $(\sim 74 \%)$ but can exhibit a flat edge or protrusion at one end. In $11 \%$ of a sample 28 population, two or more spherules are conjoined. X-ray diffraction indicates that spherule29 bearing mudstones consist mainly of muscovite, with variable amounts of kaolin-group minerals 30 and minor iron-chlorites. A range of physical origins for the spherules -- including 
31 microconcretions or metamorphic microstructures; deposition from the sky as micrometeorites,

32 microtektites/microkrystites, or accretionary volcanic ash particles; and detrital grains - is

33 considered but rejected on distributional, morphological, and mineralogical evidence. Biological

34 origins are considered most likely, especially protistan tests similar to the vase-shaped

35 microfossils found in somewhat older Neoproterozoic rocks. If correct, this provides the first

36 report of eukaryotic life in the Dalradian succession that passes critical tests for biogenicity and

37 new evidence for testate microfossils in post-Sturtian but pre-Marinoan aged rocks.

\section{KEYWORDS}

39 Biostratigraphy, Bonahaven Formation, Clay minerals, Neoproterozoic, Sturtian glaciation, 40 Vase-shaped microfossils 


\section{$43 \quad 1 \quad$ Introduction}

Over the past two decades, paleontologists have documented diverse eukaryotic fossils in

45 Neoproterozoic rocks (Knoll et al., 2006). Despite their substantial thickness and extensive outcrop, however, Dalradian strata of Scotland have played little role in these discoveries, with

47 the few existing reports being open to question (Brasier and Shields, 2000). Perhaps metamorphism has erased whatever microfossil record once existed in Dalradian strata. Or perhaps the fossils are there, hiding in plain sight.

With this possibility in mind, we re-examined micaceous spherules reported by Fairchild (1977) in moderately metamorphosed, but locally undeformed mudstones from the Dalradian Bonahaven Formation, exposed along the northeastern coast of the Isle of Islay. Fairchild (1977) hypothesized that these ca. $100 \mu \mathrm{m}$ spherules record microfossils filled penecontemporaneously with glauconite, later metamorphosed to the metamorphic mica phengite. Glauconite is known to form penecontemporaneously in the cavities of foraminiferans and other microfossils where a dysoxic environment is present (Bjerkli and Östmo-Saeter, 1973; Odin and Matter, 1981). The logic behind Fairchild's interpretation was as follows:

1. the spherules display a restricted size distribution consistent with a biological origin 2. the spherules appear to have collapsed next to desiccation cracks and hence were hollow at the time of sedimentation, and

3. spherule fillings protrude at the edges of spherule-bearing mudstone intraclasts eroded of Neoproterozoic life in the Dalradian Supergroup. However, while microfossils molded internally by authigenic minerals provide a plausible interpretation for these microstructures, it is 
impossible to rule out physical alternatives on the basis of evidence marshaled by Fairchild

67 (1977). The spherules could, in fact, have originated in three distinct ways. Firstly, they could

have originated within the sediment or rock as microconcretions or metamorphic

microstructures. Alternatively, they could have been deposited from the sky as micrometeorites, microtektites/microkrystites, or accretionary volcanic ash particles. Or, they could have originated within the ocean as detrital particles or biological remains. We combine field, petrographical, and geochemical methods to describe the distributional, morphological, and mineralogical characteristics of the Bonahaven spherules and interpret their origin.

\section{$2 \quad$ Geological Setting}

The Neoproterozoic Era, was a critical period of environmental and biological transition, during which the Earth experienced several geographically widespread glaciations set in a framework of marked carbon cycle variation, while transiting from a microbial world to one containing metazoans (Erwin et al., 2011; Gaidos et al., 2007; Hoffman et al., 1998; Knoll, 2003; Macdonald et al., 2010; McCay et al., 2006). In Scotland and Ireland, much of the Neoproterozoic Era is represented by the Dalradian Supergroup, comprised of the Grampian, Appin, Argyll and Southern Highland Groups (oldest to youngest). The Dalradian basin's ca. $25.5 \mathrm{~km}$ composite thickness is dominated by diverse marine sandstones and mudstones, most of which have been metamorphosed to psammites, pelites, and phyllites, along with volcanic rocks emplaced later in its development.

There is currently little consensus on the tectonic history of the Dalradian basin. Through facies observation, Prave (1999) proposed that the earliest sediments (the Grampian Group through the Lochaber Subgroup) were probably deposited in a rapidly subsiding foredeep associated with the mid-Neoproterozoic Knoydartian Orogeny (840-730 Ma). Prave (1999) further suggested that deposition changed to a shelf or platform setting before a late 
90 Neoproterozoic Iapetan transition from rift to drift. This interpretation contrasts with that of

91 Anderton (1982), who originally proposed a tectonic and sedimentary evolution through

92 continuous extension associated with the breakup of the supercontinent Rodinia. With either

93 hypothesis it is clear that extensional tectonics were an important contributor to upper Dalradian

94 development.

95 Few radiometric dates constrain Dalradian sedimentation. The oldest sediments postdate 96 basement dated by U-Pb analysis of monazite to $806 \pm 3 \mathrm{Ma}$ (McCay et al., 2006). Close to its 97 top, in the Southern Highlands Group, ash beds have yielded U-Pb zircon ages of $601 \pm 4 \mathrm{Ma}$ 98 and $595 \pm 4 \mathrm{Ma}$ (McCay et al., 2006).

The Bonahaven Formation and its associated spherules are situated within the Argyll

100 Group (Harris et al., 1994). The Group records two major glaciations. The Port Askaig Tillite, a $101750 \mathrm{~m}$ succession of diamictites interbedded with sandstone, conglomerate and mudstone 102 horizons, lies at the base of the Islay Subgroup, immediately below the Bonahaven Formation 103 (Spencer, 1971). A distinctive negative carbon isotope anomaly combined with characteristically 104 low ${ }^{87} \mathrm{Sr} /{ }^{86} \mathrm{Sr}$ values in carbonates below the Tillite points to a correlation with early Cryogenian 105 (Sturtian) glaciation (Brasier and Shields, 2000; Sawaki et al., 2010). Higher in the Argyll 106 Group, the Stralinchy Diamictite of Ireland has been correlated to the Marinoan Glaciation ( $~ 635$ $107 \mathrm{Ma}$ ) based on the observations of Prave et al. (2009), who reported rising $\delta^{13} \mathrm{C}_{\mathrm{V}-\mathrm{PDB}}$ values in 108 pre-glacial carbonates from $0 \%$ to $6 \%$, before a plunge to $-12 \%$ (Trezona carbon isotope 109 anomaly) and subsequent recovery to 0-2\% immediately beneath the diamictite. In contrast to 110 these chemostratigraphic and sedimentological correlations, a Re-Os date of $659.6 \pm 9$ Ma for the 111 Ballachulish Formation, which lies stratigraphically below Port Askaig beds, encourages an 112 alternative interpretation in which the Port Askaig Tillite correlates with the Marinoan glaciation 
113 (Rooney et al., 2011). Since the Bonahaven lies stratigraphically above the Port Askaig deposits 114 it must postdate Sturtian glaciation regardless of which stratigraphic interpretation is correct.

115 The 300 m thick, largely dolomitic Bonahaven Formation crops out only on the Isle of 116 Islay (Fairchild, 1985). Spencer and Spencer (1972) suggested a shallow subtidal to inter- and 117 supra-tidal environment of deposition, citing as evidence the presence of stromatolites and sub118 aerial mudcracks associated with mudflake breccias. Fairchild (1980), in turn, summarized the 119 Bonahaven succession as recording a range of shallow sub-tidal to intertidal tide- and storm120 dominated settings. Bonahaven rocks were altered by greenschist facies (biotite-grade) 121 metamorphism, reaching a maximum temperature of $<450{ }^{\circ} \mathrm{C}$ during the Ordovician-Silurian 122 Caledonian orogeny (Fairchild, 1985). Despite this regional context, perhaps uniquely for pelitic 123 rocks in the Dalradian, spherule-bearing localities display no metamorphic textures (silt-grade 124 quartzo-feldspathic detritus is still recognizable) and have no discernible tectonic fabric 125 (Fairchild, 1985, 1991; McCay et al., 2006). The formation has been subdivided into four members (Fairchild, 1985, 1991). Spherules 127 occur toward the top of Bonahaven member 1 in exposures near the coastal village of 128 Bunnahabhain (Bonahaven), where the uppermost $6 \mathrm{~m}$ of the member are exposed beneath white 129 sandstones (quartzites) of member 2. The local succession consists of millimetre- to centimetre130 scale interlaminations of dark carbonaceous mudstone and fine- to medium-grained sandstone. 131 The sandstones consist mostly of moderately sorted, subangular quartz grains with a few percent 132 feldspar, titanium-enriched iron oxides and elongate muscovite grains. The titanium-enriched 133 iron oxides commonly occur in linear arrays that run sub-parallel to bedding and which are 134 thought to be density concentrates during sedimentation. Cross-bedding occurs at several 135 horizons and dolomitic cementation is seen locally. These dolomitic sandstones tend to have 
coarser quartz grains, with some reaching a millimetre in maximum dimension. Fairchild (1977) interpreted the Bunnahabhain section in terms of tidal flat deposition, possibly close to a barrier island. Both sub-aerial desiccation cracks and sub-aqueous syneresis cracks are present within the section, suggesting a very shallow environment, episodically exposed sub-aerially. Spherulebearing horizons are also exposed further south at Caol Ila where similar interlaminated sediments occur. In this second locality, however, mudstone beds are commonly not laterally continuous.

\section{$3 \quad$ Methods}

At the two field exposures, $\sim 1 \mathrm{~km}$ south of Bunnahabhain (NR 4235 7284) and Caol Ila (NR 4280 7024), stratigraphic sections were measured through the upper part of member 1 and samples collected within this framework. At Bunnahabhain 17 samples were collected, distributed throughout a vertical section of $6.07 \mathrm{~m}$; at Caol Ila 9 samples, distributed through 4.7 m. Eight previously collected samples were also linked to these measured sections.

Size measurements were taken for 1,530 spherules from the Bunnahabhain locality using optical microscopy on thin sections in transmitted light. Size distributions were corrected for cut effects using the numerical method of Hennig and Elias (1971). In order to ensure consistent manual measurement of diameters, measurements were repeated three times for 40 spherules, with a mean standard deviation among the three measurements of $3.5 \%$.

Scanning electron microscopy (SEM) analyses, including backscatter imaging, were conducted to identify spatial patterns of chemical composition. Elemental mapping using SEM was also conducted via energy dispersive X-ray spectroscopy (EDS) on two thin-sections from the Bunnahabhain locality. Elements were chosen in accordance with Fairchild's (1977) interpretation of phengite mineralogy, with the addition of several elements of potential paleobiological interest. Therefore we mapped aluminum, calcium, carbon, magnesium, oxygen, 
160 phosphorus, potassium, silicon, and sulfur. Nickel was also mapped, as it is characteristically 161 associated with extraterrestrial deposits (Glass and Simonson, 2012; Grieve, 1991). Mapping was

162 limited to sections in which spherules were present. EDS was additionally used to target specific 163 spots on the thin-sections, commonly detrital grains identified from backscatter images. X-ray diffraction (XRD) was performed to ascertain clay mineralogy present in bulk 165 samples. Three samples from Bunnahabhain (BD004, BD008, BD014) and one from Caol Ila 166 (CID008) were analyzed. BD004 was taken from a sandstone horizon with no spherules. BD008, 167 BD014, and CID008 include sandstone and mudstone horizons, the latter containing spherules. 168 Data were acquired on $<2 \mu \mathrm{m}$ size fractions extracted from the samples (using methods outlined 169 in Moore and Reynolds, 1997), and were prepared as oriented aggregates. Samples were 170 analyzed in air-dried and glycerolated states, and again after heating for 2 hours at $400{ }^{\circ} \mathrm{C}$ to

171 identify expandable components, as well as the presence of Fe-serpentine and/or chlorite phases.

1724 Spherules: defining characteristics

$173 \quad 4.1 \quad$ Stratigraphic distribution Spherules were observed only in samples from the top $4.5 \mathrm{~m}$ of member 1 . At

175 Bunnahabhain, they occur through $3.5 \mathrm{~m}$ of section (1.5-5 $\mathrm{m}$ from the base of the exposure) and 176 at Caol Ila, they are found within the bottom $1 \mathrm{~m}$ of the exposure (Fig. 2). Notably, within these 177 sections, spherules occur only in mudstone laminae and isolated mudstone pebbles; they are 178 absent from interlaminated sandstones. At Bunnahabhain, 83\% of sampled mudstone laminae 179 contain spherules; at Caol Ila this figure rises to $100 \%$. Within the mudstones, spherules 180 constitute some $\sim 40 \%$ of the rock by volume. The presence of spherules along the margins of 181 mudstone pebbles reworked into quartz sandstones (Supp. Fig. 3) supports Fairchild's (1977) 182 hypothesis that the spherules were mineralized penecontemporaneously. Moreover, in horizons 
where soft sediment deformation has contorted laminae, spherules follow original bedding, again suggesting early emplacement. In general, the long axes of spherules align with bedding; within the plane of lamination, however, orientations are essentially random.

\subsection{Morphological Characteristics}

In thin-section, the spherules range in maximum dimension from 35 to $310 \mu \mathrm{m}$, with the modal size category being $127-150 \mu \mathrm{m}($ mean $=138 \mu \mathrm{m})($ Fig. 5). We observed no significant size variation among samples. Corrected for the under-sampling of maximum diameters, the size distribution shows no difference in modal class from the measured distribution but displays higher frequencies of spherules in the size classes that range from 150 to $242 \mu \mathrm{m}$. Spherules are circular to ovoid in thin-section. Some, however, exhibit a flat surface at the tapering end of the long axis (Fig. 4 B-F), and in some specimens this takes the form of an irregularly shaped neck-like structure, $\sim 10 \mu \mathrm{m}$ in maximum length, that protrudes into the matrix (Fig. 4 B-C E-G). Spherules illustrated in Figure $4 \mathrm{G}$ also show an indentation within their necks so that there appear to be two protrusion features in each, or an embayment created during burial compaction. It is also possible to observe conjoined spherules (Fig. $4 \mathrm{H}$ ) and deformed elliptical spherules with long-axes oriented parallel to desiccated margins (Supp. Fig. 4) (Fairchild, 1977). Notably, spherule interiors are separated from the mudstone matrix by a smoothly rounded boundary no more than a micrometre thick.

Several margins between mudstone and sandstone layers contain deformed spherules (Supp. Fig. 4). Nearing the desiccated margin, the spherules become elliptical, with their long axis parallel to the lamina margin. Critically this is seen also in bedding-parallel sections where the elliptical spherules parallel adjacent desiccation crack margins, showing the deformation was independent of burial compaction effects (Supp. Fig. 4 B). As Fairchild (1977) noted, the only 
206

207

208

209

210

211

212

213

214

215

216

217

218

219

220

221

222

223

224

225

226

227

228

possible explanation for this distributional phenomenon invokes the role of desiccation. Upon desiccation, the exposed mudstone lost water and compacted, with most severe and rapid shrinkage next to the exposed surface. Strain markers such as the emplaced spherules would record this compaction by flattening parallel to the desiccated margin. An additional observation supports the hypothesis that the structures were mineralized prior to compaction: matrix material can be seen to align to and drape over spherules (Fig. 4 D).

\subsection{Mineralogical Characteristics}

Clay minerals are prominent constituents of both the mudstone matrix and spherule interiors. In contrast, various detrital grains (EDS analysis suggests grains of apatite, titaniumenriched iron oxide and quartz) and dark materials (graphite and heavy minerals) that color the matrix are largely absent from spherule interiors. This contrast demonstrates that the spherule interior is not simply sediment matrix forced into spherule interiors. Rather, spherules were either solid entities or hollow structures filled by mineral precipitation during early diagenesis.

The latter view is supported by spherules in which a bit of matrix extends into their interior or in which low densities of graphite occur (Fig. 4 B). As noted by Fairchild (1977), some spherules display a broad orientation of crystallites perpendicular to walls in cross-polarized light, especially (Fig. 4 F; see also Fairchild (1977) plate 1).

XRD analysis of the $<2 \mu \mathrm{m}$ fraction extracted from bulk rock samples (Fig. 6) indicates that the spherule-bearing mudstone consists largely of muscovite of the $2 \mathrm{M} 1$ polytype. However, the differences between the rather common muscovite $2 \mathrm{M} 1$ structure and the far less abundant phengite $2 \mathrm{M} 1$ structure (phengite is much more commonly found in the $1 \mathrm{M}$ structure; see Bailey, 1980) are subtle, and so we cannot rule out appreciable Mg and/or Fe substitution in muscovite that would render this phase phengitic. There is also a variable amount of kaolin-group minerals 
229 in the samples, as displayed by the variation in peak intensity at $\sim 7.10 \AA$ and $3.56 \AA$. Depending

230 on the temperature to which the Bonahaven Formation was subjected during metamorphism,

231 these could represent kaolinite or dickite (Weaver, 1989). Biotite may be present in small

232 amounts but it is not a major component. Analysis after heating to $400{ }^{\circ} \mathrm{C}$ shows measureable

233 decreases in the intensity of peaks indicative of Fe serpentine/Fe-chlorite minerals such as

234 berthierine or chamosite, which are likely of early diagenetic origin or associated with

235 greenschist-facies metamorphism. The abundance of these phases compared to muscovite is

236 relatively low which reflects abundances in the $<2 \mu$ m extracted from the whole rock.

237 It might not be surprising that these metamorphosed mudstones should contain Fe-

238 bearing muscovite and chlorite; increasingly, analyses show that carbonaceous shales of the later

239 Neoproterozoic Era are commonly enriched in highly reactive Fe, sourced from ferruginous

240 water masses (Canfield et al., 2008; Johnston et al., 2010). As the Bonahaven member 1 is

241 interpreted as a coastal deposit, Fe-oxides may also have been introduced from continental

242 sources. Potential precursor minerals for the metamorphic Fe-bearing muscovite include Fe-

243 bearing smectites, which, in marine settings, are thought to form through the addition of Fe to

244 pre-existing detrital substrates under poorly-oxygenated to anoxic conditions (Meunier and El

245 Albani, 2007). Spherules do not stand out in elemental maps using EDS, suggesting no

246 differential enrichment of elements within spherules (Supp. Fig. 1).

\section{Discussion}

248 As noted above, the Bonahaven spherules could, in principle, have formed from the sky, in the

249 ocean, or within the sediments themselves. Observations of stratigraphic distribution,

250 morphology, and mineralogy, however, sharply constrain interpretation of these distinctive

251 structures. 

271 for the Bonahaven spherules.

\subsubsection{Origin from the Sky} interpetation as micrometeorites.

The spherules might have an extraterrestrial origin, as micrometeorites, microtektites, or microkrystites. Micrometerorites are small particles of cosmic origin (Onoue et al., 2011). Each year 30,000 tonnes are captured by the Earth, with 90\% being destroyed upon entry (Onoue et al., 2011). As such, discoveries of micrometeorites are rare and are confined to rocks younger than the Jurassic Period (Onoue et al., 2011). Micrometeorites are on the order of tens of microns in linear dimension, making them broadly comparable to the spherules of Fairchild (1977). However, micrometeorites are solid remains with a silicate or iron composition and distinct nickel enrichment. EDS elemental mapping analysis shows that the Bonahaven spherules are not significantly enriched in nickel and indeed reveal no mineralogical features consistent with their

Unlike micrometeorites, microtektites and microkrystites are rounded glass spherules originating from the splash debris of a bolide impact (Glass and Simonson, 2012; Kirkham, 2003; Simonson, 2003). They are famously associated with the Cretaceous-Paleogene boundary (Montanari et al., 1983) and have been identified in rocks as old as Archean (Simonson, 2003). These ejecta vary markedly in size and shape, including spheroids, elongate structures, flanged spheroids or discs, spindle-shaped forms, and dumbbells (Glass and Simonson, 2012). Breakage of barbell-shaped structures can result in elongated spheroids with truncated neck-like extensions (e.g. Bunch et al., 2012). Thus, such impact ejecta command attention as a possible explanation

Despite this comparison, morphological features cast doubt on such an interpretation, and stratigraphic observations, we think, eliminate it from consideration. Bonahaven spherules lack many of the distinctive shapes exhibited by microtektite populations, and at least some 
275 similarities are only superficial. For example, the Bonahaven population includes no true

276 dumbell-shaped individuals; where two flask-shaped individuals are conjoined, the individuals

277 are commonly separated by a thin intervening wall of matrix materials, and neither conjoined

278 spherules nor flask-shaped individuals exhibit the curvature associated with ejecta shaped by

279 viscous material in motion (e.g. Bunch et al., 2012).

280 The most compelling argument against an extraterrestrial origin, however, comes from

281 distributional characteristics. As noted previously, Bonahaven spherules (1) occur through

282 several meters of stratigraphy, and (2) are confined to mudstones. Like the Bonahaven

283 population, microtektites/microkrystites can be distributed through several meters of stratigraphy

284 (Glass and Simonson, 2012). The reason for this, however, is not that

285 microtektites/microkrystites rain down on the seafloor more or less continuously for thousands of

286 years but rather that sedimentary processes can rework ejecta formed by a single impact. This is

287 where observation 2 assumes importance. We have observed no grain-supported spherule

288 populations; all spherules "float" in a mudstone matrix. No spherules have been observed in

289 sandstone horizons through the interval in question. Thus, if the spherules are reworked, they

290 must have had a mass closer to associated clay particles than to sand grains and so could not in

291 principle have been made of silicate minerals. In combination, then, the morphological,

292 mineralogical, and distributional characters of the Bonahaven spherules seem to preclude an

293 origin as microtektites/microkrystites.

One additional potential origin from the sky is as volcanic accretionary particles --

295 coarse-grained ash ejected from a volcanic source (ash cloud or pyroclastic flow) (Schumacher

296 and Schmincke, 1991; Tucker, 2001). The type that appear most similar to the Bonahaven

297 spherules are termed lapilli. Lapilli are spherical or ellipsoidal in shape and are definied as being 
2-64 $\mathrm{mm}$ in maximum dimension although commonly include much smaller grains (Gernon et al., 2012). Lapilli generally have an enveloping rim composed of concentric rings of ash which become progressively finer in grain size or which alternate between fine and very fine sized grains (Schumacher and Schmincke, 1991). Interpretation of Bonahaven spherules as lapilli encounters the same problem as microtektite/microkrystite proposals: all spherules float in a fine-grained matrix, with few grain-grain spherule contacts, and spherules are conspicuously absent from sandstones population of quartz grains. Moreover, the spherules show neither structural evidence for concentric accretion nor evidence of originally volcanic mineralogy.

\subsubsection{Secondary Origin}

Perhaps, instead, the Bonahaven spherules originated within their matrix, during diagenesis or metamorphism. During diagenesis, authigenic minerals could form microconcretions with broadly spheroidal morphology; moreover, microconcretions might develop preferentially in mud matrices. It is less clear, however, why microconcretions would have such a sharply constrained size distribution through their stratigraphic distribution and across localtities. Nor is it obvious why the spherules should have such regular, smoothly curved boundaries, neck-like extensions or aperture-like truncations. The oriented crystal fabric originally observed by Fairchild (1977) is also problematic, in that it suggests nucleation along the bounding walls of the spherules and inwardly directed growth -- likely if mineral precipitates nucleated on a wall and grew into empty space, but not if they were accreting concretions. For these reasons, we doubt that the Bonahaven spherules represent microconcretions.

Contact metamorphism adjacent to igneous intrusions can give rise to metamorphic spots/clots, and a Cenozoic dolerite dyke is present to the south of the Bunnahabhain outcrops. Metamorphic spots are often millimetre scale and generally consist of muscovite and chlorite 
321 aggregates (Bucher and Grapes, 2011; Cruz and Galan, 2002). While the bulk mineralogy of the

322 Bonahaven spherules is compatible with such an origin, they do not exhibit the expected

323 morphology. The spherules are at least five times smaller than most described metamorphic spots

324 and do not exhibit the same colour gradation as the spots documented by Cruz and Galan (2002).

325 Moreover, while some mudstone horizons contain spherules, others do not - an unexpected

326 observation if metamorphism formed the spherules. Finally, metamorphic spots/clots do not

327 have sharp margins but are superimposed on the exisiting rock fabric with an irregular boundary

328 (Bucher and Grapes, 2011; Cruz and Galan, 2002). The Bonahaven spherules are clearly

329 differentiated from the matrix, having a micron-thick, smoothly rounded boundary. Similar

330 metamorphic clots of higher grade composed of biotite can be eliminated through mineralogical

331 data, as biotite is absent from bulk XRD analysis. Spherules within mudstone pebbles locally

332 protrude slightly into encompassing sandy laminae, indicating that these spherules were at least

333 partly mineralised prior to erosion, sand deposition and subsequent lithification (Fairchild, 1977).

334 This casts still more doubt on a metamorphic origin, as does the apparent shrinkage of spherules

335 parallel to desiccation margins.

$336 \quad$ 5.1.3 Origin from the Ocean

337 The final potential source for the spherules is the surrounding ocean. An origin as

338 terrigenous detritus can be dismissed as follows. Detritus is observed throughout the mudstone in

339 the mineralogical form of apatite, feldspar, titanium-enriched iron oxides, and quartz, each on the

340 order of a few microns in linear dimension, with occasional grains reaching $40 \mu \mathrm{m}$-- much

341 smaller than maximum grain size in interlaminated sandstones. The spherules do not have a

342 mineralogical composition similar to those of unambiguous detrital grains, and they are evenly

343 rounded, unlike subangular detritus. Moreover, the spherules possess few distributional features 
344 characteristic of detrital grains; spherules are restricted to mudstone horizons and are much

345 larger than encompassing silicate grains. Furthermore, were they restricted by facies, detrital

346 spherules would be unlikely to sort mechanically with the mud due to difference in volume and

347 mass between the two. Hydrodynamically, then, the spherules are out of place in the mudstones, 348 unless they were hollow.

Fairchild (1977) considered a further origin from the oceans: replacement of fecal pellets.

350 There is, however, no confirmed evidence that macroscopic metazoans existed at the time of

351 deposition. Nor would fecal pellets show the range of morphologies displayed in the Bonahaven

352 spherules. Moreover, the collapse of spherules next to desiccated margins indicates they were not 353 initially solid objects.

\section{$354 \quad 5.2 \quad$ Biological Origin}

Having dismissed potential physical origins, we return to Fairchild's (1977) original

356 paleobiological interpretation. A problem with the fossil-infill hypothesis, particularly at the time 357 it was proposed, is that most Neoproterozoic microfossils of appropriate size are mechanically 358 weak and collapse to essentially two-dimensional compressions in mudstone matrices (e.g., 359 Knoll, 1996). Three-dimensionally preserved fossils filled with authigenic chert are known from 360 micrites, but they have irregular shapes that document compression prior to silica emplacement 361 (Knoll et al., 1991). The exception is vase-shaped microfossils, elongate tests originally 362 discovered in 1933 and rediscovered the year Fairchild reported on the Dalradian microstructures 363 (Bloeser et al., 1977). Interpreted as the tests of amoebozoans and rhizarians based on 364 exceptionally preserved $\sim 742$ Ma examples from carbonate nodules in basinal shales two meters 365 below a $742 \pm 6 \mathrm{Ma}$ ash bed in the uppermost Chuar Group, Grand Canyon (Porter and Knoll, 366 2000; Porter et al., 2003), vase-shaped fossils are widely distributed in ca. 800-740 Ma rocks, 
where they are routinely preserved three-dimensionally in fine-grained lithofacies as mineralinfilled casts and molds with no trace of original wall material (Porter and Knoll, 2000, and references therein). Their shape preserved due to the mechanical strength of vase walls, these tests were cast and infilled prior to significant compaction and before organic decay proceeded to completion. Like other coeval VSMs, the Chuar Group microfossils are cup- to tear-shaped tests that appear circular in transverse section and taper toward a single opening at one end while rounding or flaring to an aboral pole at the other (Porter and Knoll, 2000). Their size ranges from $25-160 \mu \mathrm{m}$ in length and $15-105 \mu \mathrm{m}$ in width, with length to width ratos between 1:1 and 3:1. The majority are radially symmetric; however, around $25 \%$ are bilaterally symmetric with a curved neck. The neck is thought to represent an aperture and is between 5-40 $\mu \mathrm{m}$ maximum cross-sectional dimension (Porter and Knoll, 2000). Some Chuar Group VSMs also preserve a record of the organic wall as early diagenetic pyrite 1-3 $\mu \mathrm{m}$ thick (Porter and Knoll, 2000), but in most occurrences all traces of the actual wall have been lost to decay (Knoll and Calder, 1983). Bonahaven spherules possess many of the morphological and distributional features noted for vase-shaped microfossils, including shape, size frequency distribution, and preservational mode. Distributionally, we know the Bonahaven spherules are restricted to mud laminae and isolated mud pebbles. Similarly, VSM assemblages are documented from carbonate and shale successions but not grainstones, likely because their tests decayed too rapidly for preservation in coarser sediments (Knoll, 1996; Porter and Knoll, 2000). In terms of size the Bonahaven spherules are broadly similar to Chuar Group VSMs, although the Chuar assemblage contains more specimens under $70 \mu \mathrm{m}$ long. We can also compare the vase-like shape. The best documented morphological feature of VSMs is their oral aperture, preserved as a neck structure (Porter and Knoll, 2000; Porter et al., 2003). Noting that modern testate protists vary widely in 
morphology, we can still ask whether Bonahaven spherules also preserve this feature. A majority do not, but then the aperture is not apparent in most Chuar VSMs observed in thin section. The reason for this is that the plane of section is more or less randomly oriented with respect to the test morphology, and many sections cut obliquely across tests, missing the aperture. To compare unambiguous VSM populations observed in thin section with the Bonahaven spherules, we counted sample populations of Bonahaven spherules, Chuar Group VSMs (Porter and Knoll, 2000), and VSMs from the Draken Formation, Svalbard (Knoll et al., 1991), assigning individuals to one of four shape categories: rounded, rounded with a flat edge, rounded with protruding aperture structure, and conjoined.

Figure 8 highlights the similarity in shape distribution among the three sets of specimens, with each showing at least $74 \%$ rounded specimens and low values for specimens with protruding necks $(\sim 3 \%)$. The only major difference between the Bonahaven spherules and the unambiguous VSMs is that the Bonahaven spherules have a higher proportion of conjoined specimens: $11 \%$ compared to the $2 \%$ and $1 \%$ we observed in the Chuar Group and Draken Formation, respectively. Conjoined VSMs in the Uinta Group, which is correlative to the fossiliferous Chuar succession, were interpreted by Porter et al. (2003) as documenting asexual reproduction of testate amoebae (Fig. 9). During mitotic cell division, the daughter and mother cells remain attached at the aperture until division is complete (Porter et al., 2003). The higher proportion of conjoined specimens in the Bonahaven spherules might suggest that the fossilization process captured more specimens in reproductive mode. However, it might just be that the subsequent metamorphism brought some specimens into close contact.

If we remove the conjoined specimens from our analysis (Fig. 8) the Bonahaven spherules are distributed in exactly the same proportions as the Chuar VSMs and are similar to 
413 those of the Draken Formation. We can therefore infer that the preserved test structure has a

414 similar distribution of oblique cross-sections in each assemblage, and thus the Bonahaven

415 oblique sections capture the distinguishing morphological feature of VSMs, the aperture, to the

416 same extent as those taken from rocks containing unambiguous VSMs. Such similarities in

417 morphological features and facies-restricted preservation between the Bonahaven spherules and

418 the broad class of testate organisms represented by the VSMs, support interpretation of the

419 Bonahaven spherules as biological, and more specifically as penecontemporaneous internal

420 molds of structurally rigid walls such as those found in Neoproterozoic VSMs and living testate

421 amoebae. The broad orientation of crystallites perpendicular to walls observed in some spherule

422 interiors is consistent with nucleation of infilling prepitates on the internal surfaces of test walls

423 later obliterated by organic decay.

\section{Proposed Origin as Testate Microorganisms}

425 Summing available observations of morphology, chemistry and stratigraphic distribution

426 - and acknowledging remaining uncertainties -- we propose the following explanation for the

427 Bonahaven spherules:

4281 Testate microorganisms lived in the local environment represented by Bonahaven

429 siliciclastics: a shallow tidal setting likely close to a barrier island.

4302 Upon death, evacuated tests were deposited from suspension along with muddy

$431 \quad$ sediments.

4323 Localized strong shrinkage of the mudstone caused by desiccation led to collapse and hence elongation of spherules adjacent to desiccated margins.

4 Penecontemporaneously, an iron-enriched mineral filled in the tests. We can eliminate a mechanical in-fill by surrounding mud sediments as there is a contrast in abundance 
The evidence for iron enrichment comes from the bulk mineralogy suggested by XRD analysis. The iron-enriched muscovite and minor iron-serpentine/iron-chlorite observed today likely arose as metamorphic products of an iron-enriched precursor during Caledonian orogenesis. An iron-bearing smectite is thought to be the most

6 Subsequent tectonic deformation and metamorphism during the Caledonian Orogeny and later plate movements subjected the rocks to temperatures possibly up to $450{ }^{\circ} \mathrm{C}$ and pressures less than 8 kbar, based on regional context (Fairchild 1977) and minerals characteristic of the greenschist metamorphic facies. As a result the bulk mineralogy changed to muscovite (potentially phengitic) of the $2 \mathrm{M} 1$ polytype, as observed by XRD analysis. At some point during this process the organic wall of the organism decayed and was not preserved. We do not know when this occurred, but an intact wall would have been required to sustain the three dimensional morphology of the test at least until encompassing sediments became lithified and/or the mold became infilled by minerals.

\section{$\begin{array}{lll}458 & 7 & \text { Implications for the Record of Neoproterozoic Life }\end{array}$}



protists preserved in of the Chuar Group and correlative rocks provides two new perspectives on

461 Neoproterozoic eukaryotic life. Firstly, it provides a record of protists in the Dalradian

462 Supergroup, where few fossils have previously been documented. Brasier and Shields (2000)

463 reported no eukaryotic micro- or macrofossils in Dalradian rocks of Neoproterozoic age and

464 suggested that all previously proposed evidence, including possible trace fossils and macrofossils 465 of Ediacaran faunas, can be attributed to physical origins.

The second perspective is that testate protists lived in coastal oceans between

467 Neoproterozoic Snowball Earth events (Hoffman et al., 1998; Macdonald et al., 2010). The 468 evolutionary impact of Neoproterozoic ice ages remains poorly known, in part because few 469 microfossils are documented from rocks deposited between the two principal glaciations (Knoll 470 et al, 2006; Macdonald et al., 2010). VSM taxa preserved in the Chuar and Draken assemblages 471 have been found only in rocks deposited before the Sturtian glaciation, with the exception of 472 some reported from the Kingston Peak Formation, Death Valley that are potentially synglacial in 473 age (Corsetti et al., 2003; Licari, 1978; Walker et al., 1986). If chemo- and lithostratigraphic 474 assignment of the Port Askaig Tillite to the Sturtian ice age is correct, then the Bonahaven 475 Formation lies within the between-glacial interval (Brasier and Shields, 2000). As noted 476 previously, the Re-Os date for the Ballachulish Formation of $659 \pm 9 \mathrm{Ma}$ (Rooney et al., 2011) 477 calls into question this stratigraphic correlation, but even if we accept this date and reinterpret the 478 Port Askaig as Marinoan, the Bonahaven spherules would postdate the Sturtian glaciation and so 479 be younger than Chuar and correlative VSMs. Recently, Bosak et al. (2012) interpreted small tubular structures from post-Sturtian cap 481 carbonates of the Rasthof Formation, Namibia, as microfossils with affinities to modern single- 
482 chambered, agglutinated foraminiferans. Also, Bosak et al. (2011) reported agglutinated tests

483 from Namibia and Mongolia, which they attributed to lobose testate amoebae and, perhaps, other

484 heterotrophic protists. However one interprets the microstructures of Bosak et al. (2011), they do

485 not record the same types of testate protists as those found so abundantly in pre-Sturtian rocks.

486 Pre-Sturtian aged VSMs are compared mostly with the lobose testate amoebae families

487 Arcellidae, Trygonopyxidae, Difflugiidae, Hyalosphenidae, and Lesquereusiidae (Porter et al.,

488 2003). In contrast the Rasthof Formation contains structures attributed to lobose testate amoebae

489 families Heloperidae, Plagiopyxidae, and Difflugiidae, identified by aperture affinities to modern

490 amoebozoans (Bosak et al., 2011). One may then ask whether the Bonahaven spherules, being

491 post-Sturtian in age, are more similar in morphology to the testate microfossils of Bosak et al.

492 (2011) than to those VSMs from pre-Sturtian strata. The testate microfossils reported by Bosak

493 et al. (2011) are 30-290 $\mu \mathrm{m}$ long axis and 30-170 $\mu \mathrm{m}$ wide. In contrast, only $4 \%$ of the

494 Bonahaven specimens measured in thin-section are larger than $190 \mu \mathrm{m}$ in maximum dimension.

495 Yet they are not as small as the pre-Sturtian VSMs and so likely sit between the two assemblages

496 in size. In terms of morphology the Bonahaven specimens resemble unambiguous pre-Sturtian

497 VSMs (Fig. 8), but do not belong to the same taxa as these earlier counterparts. Finally, there are

498 no visible concentrations of grains along spherule boundaries and so no evidence that the

499 Bonahaven spherules possessed agglutinated tests like the Rasthof microfossils. Consequently,

500 their size, shape, and wall characteristics make it unlikely that the Bonahaven spherules are

501 comparable to the populations reported by Bosak et al. (2011). Instead, despite their considerable

502 age difference, they are broadly similar to pre-Sturtian assemblages, with possible affinities to

503 the extant testate amoeban families Nebelidae, Hyalosphenidae, and Difflugiidae (Lahr, personal

504 communication, 2012). Other vase-like microfossils have been described from younger 
505 sediments; however, these are thought to represent quite different taxa. For example, Hua et al.

506 (2010) report VSMs larger in size (600- $2400 \mu \mathrm{m})$ from the Ediacaran Dengying Formation

507 (551-541 Ma) thought to be associated with foraminifera. VSMs are not seen again until at least

508 the Carboniferous Period (Wightman et al., 1994).

\section{Conclusions}

510 Microscopic spherules first described and interpreted as glauconitized microfossils by

511 Fairchild (1977) are here interpreted as the metamorphosed casts and molds of testate amoebae

512 broadly comparable to those well documented from pre-Sturtian assemblages. Distributional,

513 morphological, and mineralogical features are shared by both the Bonahaven spherules and

514 unambiguous VSM assemblages. It is inferred from XRD analyses that the organic-walled tests

515 were in-filled penecontemporaneously to sedimentation with an iron-bearing mineral (probably

516 smectite) before the wall was lost to decay. Iron is hypothesized to have been sourced either

517 from local ferruginous Neoproterozoic water masses or from the geographically proximal

518 continents. If correct, the Bonahaven spherules provide the first record of eukaryotic life within

519 the Dalradian Supergroup of Scotland. They also furnish an example of VSMs broadly similar to

520 those observed in the pre-Sturtian Chuar Group and Draken Formation, but separated from these

521 older deposits by (minimally) Sturtian glaciation. 
523

524

525

526

527

528

529

530

531

532

\section{ACKNOWLEDGMENTS}

Research leading to this paper was supported in part by the NASA Astrobiology Institute. Field work funding provided by the Harvard Origins of Life Initiative 2011 Summer Undergraduate Research Fellowship and the Department of Earth and Planetary Sciences, Harvard University.

This work was performed in part at the Center for Nanoscale Systems (CNS), a member of the National Nanotechnology Infrastructure Network (NNIN), which is supported by the National Science Foundation under NSF award no. ECS-0335765. CNS is part of Harvard University.

We thank David Johnston, Daniel Lahr, and Bruce Simonson for providing constructive comments and insights into the realms of geochemistry, modern testate microorganisms, and impact spherules respectively.

We thank Phoebe Cohen for assistance in operating the SEM, and Emily Macmillan and Edward Fleming for assistance in the field and at the University of Birmingham.

\section{APPENDIX}

Supplementary Figure 1: Scanning electron microscopy analysis of thin-section PB-I14 using back-scatter and EDS elemental mapping techniques. Scale bar is $200 \mu \mathrm{m}$. Sample level can be obtained from Figure 2. Analyses conducted using SUPRA 55VP-30-48 348x EHT $15.05 \mathrm{kV}$ at the Harvard Center for Nanoscale Systems. Top Left: Back-scatter image of mudstone horizon containing spherules showing an example spherule outlined in red, other spherules denoted by lack of detritus. Above: Microprobe elemental density maps showing general homogeneity across the thin-section. Bottom Right: Location of analysis depicted on flat-bed scan of thinsection.

Supplementary Figure 2: EDS analysis of mudstone horizon within thin-section BD013B showing characteristic elemental peaks. All scale bars are $100 \mu \mathrm{m}$. Sample level can be obtained from Figure 2. Analyses conducted using SUPRA 55VP-30-48 $20 \mathrm{kV}$ amp 25 at the Harvard Center for Nanoscale Systems. A: Back-scatter image showing target location for matrix. B: Elemental composition of matrix showing characteristic elements of muscovite. C: Back-scatter image showing target grain for D. D: Elemental composition characteristic of quartz. E: Backscatter image showing target grain for F. F: Elemental composition characteristic of titaniumenriched iron oxide. G: Back-scatter image showing target grain for H. H: Elemental composition characteristic of apatite. 
Supplementary Figure 3: Photomicrographs of thin-sections showing Bonahaven spherules in a mudstone intraclast penetrating sandstone interlaminations and sometimes truncating at the margins. Coordinates reported for England Finder with thin-section orientated so that fixed corner is next to thin-section label. Scale given in images. A: Image courtesy Fairchild (1977). B: $485332 \mathrm{U} 45 / 0$.

Supplementary Figure 4: Collapsed spherules next to desiccated margins. Coordinates reported for England Finder with thin-section orientated so that fixed corner is next to thin-section label. A: Photomicrograph of desiccated mud margin in bedding perpendicular thin-section showing spherules elongated with long axis parallel to desiccated margin. Scale bar is $300 \mu \mathrm{m}$. B: Photomicrograph of desiccated mud margin in bedding parallel thin-section showing spherules elongated with long axis parallel to desiccated margin, $485332 \mathrm{R} 28 / 4$. Scale bar is $300 \mu \mathrm{m}$. C: Drawing of bedding perpendicular thin-section showing spherule bearing mudstone horizons and desiccated areas. Images A and C courtesy Fairchild (1977).

\section{REFERENCES}

Anderton, R., 1982. Dalradian Deposition, the Late Precambrian-Cambrian History of the N Atlantic Region and the Early Evolution of the Iapetus Ocean. J. Geol. Soc. 139, 222-222.

Bailey, S.W., 1980. Structures of Layered Silicates, in: Brindley, G.W., Brown, G. (Eds.), Crystal Structures of Clay Minerals and Their X-Ray Identification. Mineralogical Society, London, pp. 1-124.

Bjerkli, K., Östmo-Saeter, J.S., 1973. Formation of Glauconite in Foraminiferal Shells on Continental-Shelf Off Norway. Marine Geology 14, 169-178.

Bloeser, B., Schopf, J.W., Horodyski, R.J., Breed, W.J., 1977. Chitinozoans from Late Precambrian Chuar Group of Grand-Canyon, Arizona. Science 195, 676-679.

Bosak, T., Lahr, D.J.G., Pruss, S.B., Macdonald, F.A., Dalton, L., Matys, E., 2011. Agglutinated Tests in Post-Sturtian Cap Carbonates of Namibia and Mongolia. Earth and Planetary Science Letters 308, 29-40.

Bosak, T., Lahr, D.J.G., Pruss, S.B., Macdonald, F.A., Gooday, A.J., Dalton, L., Matys, E.D., 2012. Possible Early Foraminiferans in Post-Sturtian (716-635 Ma) Cap Carbonates. Geology 40, 67-70.

Brasier, M.D., Shields, G., 2000. Neoproterozoic Chemostratigraphy and Correlation of the Port Askaig Glaciation, Dalradian Supergroup of Scotland. J. Geol. Soc. 157, 909-914.

Bucher, K., Grapes, R., 2011. Petrogenesis of Metamorphic Rocks, 8 ed. Springer, Berlin.

Bunch, T.E., Hermes, R.E., Moore, A.M.T., Kennett, D.J., Weaver, J.C., Wittke, J.H., DeCarli, P.S., Bischoff, J.L., Hillman, G.C., Howard, G.A., Kimbel, D.R., Kletetschka, G., Lipo, C.P., Sakai, S., Revay, Z., West, A., Firestone, R.B., Kennet, J.P., 2012. Very High-Temperature Impact Melt Products as Evidence for Cosmic Airbursts and Impacts 12,900 Years Ago. Proceedings of the National Academy of Sciences of the United States of America 109, E1903E1912. 
Callegari, E., Pertsev, N.N., 2007. Contact Metamorphic Rocks.

592 Canfield, D.E., Poulton, S.W., Knoll, A.H., Narbonne, G.M., Ross, G., Goldberg, T., Strauss, H., 593 2008. Ferruginous Conditions Dominated Later Neoproterozoic Deep-Water Chemistry. Science $594321,949-952$.

595 Corsetti, F.A., Awramik, S.M., Pierce, D., 2003. A Complex Microbiota from Snowball Earth 596 Times: Microfossils from the Neoproterozoic Kingston Peak Formation, Death Valley, USA.

597 Proceedings of the National Academy of Sciences of the United States of America 100, 43995984404.

599 Cruz, M.D.R., Galan, E., 2002. Mineralogy and Origin of Spots in Spotted Slate from the 600 Malaguide Complex, Betic Cordilleras, Spain: An XRD, EMPA and TEM-AEM Study. 601 Canadian Mineralogist 40, 1483-1503.

602 Dressler, B.O., Reimold, W.U., 2001. Terrestrial Impact Melt Rocks and Glasses. Earth-Science 603 Reviews 56, 205-284.

604 Elliston, J., 1968. Retextured sediments. XXIII Int. geol. Cong. 8, 85-104.

605 Erwin, D.H., Laflamme, M., Tweedt, S.M., Sperling, E.A., Pisani, D., Peterson, K.J., 2011. The 606 Cambrian Conundrum: Early Divergence and Later Ecological Success in the Early History of 607 Animals. Science 334, 1091-1097.

608 Fairchild, I.J., 1977. Phengite Spherules from Dalradian Bonahaven Formation, Islay, Scotland 609 Glauconitized Microfossils. Geological Magazine 114, 355-364.

610 Fairchild, I.J., 1980. Stages in a Precambrian Dolomitization, Scotland - Cementing Versus 611 Replacement Textures. Sedimentology 27, 631-650.

612 Fairchild, I.J., 1985. Petrography and Carbonate Chemistry of Some Dalradian Dolomitic 613 Metasediments - Preservation of Diagenetic Textures. J. Geol. Soc. 142, 167-185.

614 Fairchild, I.J., 1991. Itinerary Ii: Topmost Islay Limestone (Appin Group), Port Askaig and 615 Bonahaven Formations (Argyll Group) Port Askaig Area, Islay, in: Hambrey, M.J., Fairchild, 616 I.J., Glover, B.W., Stewart, A.D., Treagus, J.E., Winchester, J.A. (Eds.), Geologists's Assocation 617 Guide No. 44: The Late Precambrian Geology of the Scottish Highlands and Islands. The 618 Geologists' Association, London.

619 Gaidos, E., Dubuc, T., Dunford, M., McAndrew, P., Padilla-Gamino, J., Studer, B., Weersing, 620 K., Stanley, S., 2007. The Precambrian Emergence of Animal Life: A Geobiological Perspective. 621 Geobiology 5, 351-373.

622 Gernon, T.M., Brown, R.J., Tait, M.A., Hincks, T.K., 2012. The origin of pelletal lapilli in 623 explosive kimberlite eruptions. Nature Communications 3, Article Number: 832, DOI: $62410.1038 /$ ncomms 1842.

625 Glass, B.P., Simonson, B.M., 2012. Distal Impact Ejecta Layers: Spherules and More. Elements $6268,43-48$.

627 Grieve, R.A.F., 1991. Terrestrial Impact - the Record in the Rocks. Meteoritics 26, 175-194. 
Harris, A.L., Haselock, P.J., Kennedy, M.J., Mendum, J.R., 1994. The Dalradian Supergroup in Scotland, Shetland and Ireland., in: Gibbons, W., Harris, A.L. (Eds.), A Revised Correlation of Precambrian Rocks in the British Isles. The Geological Society, Bath, pp. 33-53.

Hennig, A., Elias, H., 1971. Rapid Method for Visual Determination of Size Distribution of Spheres from Size Distribution of Their Sections. J. Microsc.-Oxf. 93, 101-\&.

Hoffman, P.F., Kaufman, A.J., Halverson, G.P., Schrag, D.P., 1998. A Neoproterozoic Snowball Earth. Science 281, 1342-1346.

Hua, H., Chen, Z., Yuan, X., Xiao, S., Cai, Y., 2010. The Earliest Foraminifera from Southern Shaanxi, China. Science China-Earth Sciences 53, 1756-1764.

Johnston, D.T., Poulton, S.W., Dehler, C., Porter, S., Husson, J., Canfield, D.E., Knoll, A.H., 2010. An Emerging Picture of Neoproterozoic Ocean Chemistry: Insights from the Chuar Group, Grand Canyon, USA. Earth and Planetary Science Letters 290, 64-73.

Kirkham, A., 2003. Glauconitic Spherules from the Triassic of the Bristol Area, SW England: Probable Microtektite Pseudomorphs. Proceedings of the Geologists Association 114, 11-21.

Knoll, A.H., 1996. Archean and Proterozoic Paleontology, in: Jansonius, J., McGregor, D.C. (Eds.), Palynology: Principles and Applications. Publishers Press, Utah, pp. 51-80.

Knoll, A.H., 2003. Life on a Young Planet: The First Three Billion Years of Evolution on Earth. Princeton University Press, Princeton.

Knoll, A.H., Calder, S., 1983. Microbiotas of the Late Precambrian Rysso Formation, Nordaustlandet, Svalbard. Palaeontology 26, 467-496.

Knoll, A.H., Javaux, E.J., Hewitt, D., Cohen, P., 2006. Eukaryotic Organisms in Proterozoic Oceans. Philosophical Transactions of the Royal Society B-Biological Sciences 361, 1023-1038.

Knoll, A.H., Swett, K., Mark, J., 1991. Paleobiology of a Neoproterozoic Tidal Flat Lagoonal Complex - the Draken Conglomerate Formation, Spitsbergen. Journal of Paleontology 65, 531570 .

Licari, G.R., 1978. Biogeology of Late Pre-Phanerozoic Beck Spring Dolomite of Eastern California. Journal of Paleontology 52, 767-792.

Macdonald, F.A., Schmitz, M.D., Crowley, J.L., Roots, C.F., Jones, D.S., Maloof, A.C., Strauss, J.V., Cohen, P.A., Johnston, D.T., Schrag, D.P., 2010. Calibrating the Cryogenian. Science 327, 1241-1243.

McCay, G.A., Prave, A.R., Alsop, G.I., Fallick, A.E., 2006. Glacial Trinity: Neoproterozoic Earth History within the British-Irish Caledonides. Geology 34, 909-912.

Meunier, A., El Albani, A., 2007. The Glauconite-Fe-Illite-Fe-Smectite Problem: A Critical Review. Terra Nova 19, 95-104.

Montanari, A., Hay, R.L., Alvarez, W., Asaro, F., Michel, H.V., Alvarez, L.W., Smit, J., 1983. Spheroids at the Cretaceous-Tertiary Boundary Are Altered Impact Droplets of Basaltic Composition. Geology 11, 668-671.

Moore, D.M., Reynolds, R.C., 1997. X-Ray Diffraction and the Identification and Analysis of Clay Minerals. Oxford University Press. 
Odin, G.S., Matter, A., 1981. Origin of Glauconites. Sedimentology 28, 611-641.

668 Onoue, T., Nakamura, T., Haranosono, T., Yasuda, C., 2011. Composition and Accretion Rate of 669 Fossil Micrometeorites Recovered in Middle Triassic Deep-Sea Deposits. Geology 39, 567-570.

670 Porter, S.M., Knoll, A.H., 2000. Testate Amoebae in the Neoproterozoic Era: Evidence from

671 Vase-Shaped Microfossils in the Chuar Group, Grand Canyon. Paleobiology 26, 360-385.

672 Porter, S.M., Meisterfeld, R., Knoll, A.H., 2003. Vase-Shaped Microfossils from the

673 Neoproterozoic Chuar Group, Grand Canyon: A Classification Guided by Modern Testate

674 Amoebae. Journal of Paleontology 77, 409-429.

675 Prave, A.R., 1999. The Neoproterozoic Dalradian Supergroup of Scotland: An Alternative 676 Hypothesis. Geological Magazine 136, 609-617.

677 Prave, A.R., Fallick, A.E., Thomas, C.W., Graham, C.M., 2009. A Composite C-Isotope Profile 678 for the Neoproterozoic Dalradian Supergroup of Scotland and Ireland. J. Geol. Soc. 166, 845679857.

680 Rooney, A.D., Chew, D.M., Selby, D., 2011. Re-Os Geochronology of the Neoproterozoic681 Cambrian Dalradian Supergroup of Scotland and Ireland: Implications for Neoproterozoic 682 Stratigraphy, Glaciations and Re-Os Systematics. Precambrian Research 185, 202-214.

683 Sawaki, Y., Kawai, T., Shibuya, T., Tahata, M., Omori, S., Komiya, T., Yoshida, N., Hirata, T., 684 Ohno, T., Windley, B.F., Maruyama, S., 2010. Sr-87/Sr-86 Chemostratigraphy of

685 Neoproterozoic Dalradian Carbonates Below the Port Askaig Glaciogenic Formation, Scotland. 686 Precambrian Research 179, 150-164.

687 Schumacher, R., Schmincke, H.U., 1991. Internal Structure and Occurrence of Accretionary 688 Lapilli - a Case-Study at Laacher See Volcano. Bulletin of Volcanology 53, 612-634.

689 Simonson, B.M., 2003. Petrographic Criteria for Recognizing Certain Types of Impact Spherules 690

691

692

693

694

695

696

697

698

699

700

701

702

703 in Well-Preserved Precambrian Successions. Astrobiology 3, 49-65.

Spencer, A.M., 1971. Late Pre-Cambrian Glaciation in Scotland. The Geological Society, London, Memoirs, 6.

Spencer, A.M., Spencer, M.O., 1972. The Late Precambrian/Lower Cambrian Bonahaven Dolomite of Islay and Its Stromatolites. Scottish Journal of Geology 8, 269-282.

Tucker, M.E., 2001. Sedimentary Petrology, 3 ed. Blackwell Publishing, Oxford.

Walker, J.D., Klepacki, D.W., Burchfiel, B.C., 1986. Late Precambrian Tectonism in the Kingston Range, Southern-California. Geology 14, 15-18.

Weaver, C.E.C.E., 1989. Clays, Muds, and Shales. Elsevier, Amsterdam; New York.

Wightman, W.G., Scott, D.B., Medioli, F.S., Gibling, M.R., 1994. Agglutinated Foraminifera and Thecamoebians from the Late Carboniferous Sydney Coalfield, Nova-Scotia - Paleoecology, Paleoenvironments and Paleogeographic Implications. Palaeogeography Palaeoclimatology Palaeoecology 106, 187-202.

\section{FIGURE CAPTIONS}

705

Figure 1: A: Map showing the geographic location of the Isle of Islay. B: Generalized stratigraphy of the Dalradian Supergroup and Bonahaven Formation showing spherule-bearing 
horizons. Note that the Bonahaven Formation lies stratigraphically above the Port Askaig Tillite. Adapted from Fairchild (1985); Rooney et al. (2011).

Figure 2: A: Map showing the local geology at both Caol Ila (left) and Bunnahabhain (right), arrows denote section locations. Both sections comprise strata from member 1 of the Bonahaven Formation. B: Stratigraphy of section taken $1 \mathrm{~km}$ south of Bunnahabhain showing sample locations and spherule bearing horizons. C: Stratigraphy of section taken north of Caol Ila showing sample locations and spherule bearing horizons. D: Key to lithologies.

Figure 3: Flat-bed scanned image of thin-section 485332 b showing spherule abundance within mudstone horizons. Section taken perpendicular to bedding. Scale bar is $10 \mathrm{~mm}$. Sample Level can be obtained from Figure 2.

Figure 4: Spherule morphologies in petrographic thin-section $30 \mu \mathrm{m}$ thickness under plane polarized light unless indicated. All scale bars are $100 \mu \mathrm{m}$. Sample levels can be obtained from Figure 2. Coordinates reported for England Finder with thin-section orientated so that fixed corner is next to thin-section label. A: photomicrograph showing spherule density within mudstone horizons, $485332 \mathrm{U} 41 / 0$. B: photomicrograph of two spherules ( $\mathrm{m}$ and $\mathrm{n}$ ) overlapping. The nearest (n) shows a flat edge (arrow) and a central line of dark material likely composed of graphite and pyrite, PB-I8 G39/2. C: photomicrograph of spherule with flat edge (arrow) 485332 K37/1. D: photomicrograph of spherule with flat edge (p) showing mudstone (q) draping around spherule, 485332 with coordinates $(39.3,188,3)$ on microscope where Z36 is $(39.4,116.1)$. E: photomicrograph showing two spherules with tapering necks (arrows), 485332 M41/1. F: photomicrograph showing the same two spherules as E under cross-polarized light emphasizing the broad orientation of crystallites perpendicular to walls, $485332 \mathrm{M} 41 / 1$. G: photomicrograph of two spherules both with neck like structures including spherule with indentation (right), PBI11B R30. H: photomicrograph of conjoined spherules, $485332 \mathrm{~L} 47 / 3$.

Figure 5: Histograms of size distribution of spherules. Top: Distribution based on measured maximum diameters from petrographic thin-section. Bottom: Corrected distribution using the method of Hennig and Elias (1971) and assumptions/coefficients of Fairchild (1977) to account for cut effects in petrographic thin-section. Size classes were chosen to accommodate the correction method.

Figure 6: XRD representative scan of less than $2 \mu \mathrm{m}$ fractions extracted from bulk composition using a Co K $\alpha$ source plotting intensity versus diffraction angle (20). Sample Levels can be obtained from Figure 2. A: BD004. B: BD008. C: BD014. D: CID008. Black dots represent peaks associated with kaolin-group minerals. All other peaks associated with micas. Each scan shows clear $h k l$ peaks belonging to muscovite of the $2 \mathrm{M} 1$ polytype.

Figure 7: Chart depicting the multiple lines of evidence upon which each physical mode of origination for the spherules was rejection (based on defining characteristics of physical phenomena from Bucher and Grapes, 2011; Callegari and Pertsev, 2007; Cruz and Galan, 2002; Dressler and Reimold, 2001; Glass and Simonson, 2012; Grieve, 1991; Kirkham, 2003; Montanari et al., 1983; Onoue et al., 2011; Schumacher and Schmincke, 1991; Simonson, 2003; Tucker, 2001). The lines of evidence are separated into three distinct categories: distributional, morphological, and mineralogical. 
747 Figure 8: Results of morphological two-dimensional shape comparison showing similarities 748 between unambiguous VSMs and the Bonahaven spherules. The number of individuals counted 749 in each case is given as $n$.

750 Figure 9: Photomicrographs of unambiguous VSMs, Bonahaven Spherules, and modern 751 analogues for comparison. All scale bars represent $50 \mu \mathrm{m}$. Sample levels can be obtained from 752 Figure 2. Where coordinates reported, they are England Finder coordinates with thin-section 753 orientated so that fixed corner is next to thin-section label. A: VSMs attached at the aperture 754 suggested reproductive stage (Porter et al., 2003). B: Bonahaven conjoined spherules showing 755 similarities to A, 485332 L47/3. C: VSM from the Draken Formation preserved as silica-filled 756 internal mould in dolomite (Knoll et al., 1991). D: Bonahaven spherule showing similar aperture 757 to C, 485332 with coordinates $(39.3,188.3)$ on microscope where Z36 is $(39.4,116.1)$. E: VSM 758 from Upper Walcott population (Porter and Knoll, 2000). F: Modern Hyalosphenia papilio with 759 organic test (courtesy of Lahr).

760 Figure 10: Stages of proposed origination from Neoproterozoic testate organism to VSM 761 preserved within siliciclastic sediments of the Bonahaven Formation. 
1

2 3

\section{AUTHORS}

5 Ross P. Anderson*1 ${ }^{1}$, Ian J. Fairchild ${ }^{2}$, Nicholas J. Tosca ${ }^{3}$, and Andrew H. Knoll ${ }^{4}$

6

7

8

\section{TITLE}

Microstructures in metasedimentary rocks from the Neoproterozoic Bonahaven Formation, Scotland: Microconcretions, microtektitesimpact spherules, or microfossils?

*corresponding author

\section{AFFILIATIONS}

${ }^{1}$ Department of Earth and Planetary Sciences, Harvard University, 20 Oxford Street, Cambridge, MA, 02138 USA. Present address: Department of Geology and Geophysics, Yale University, 210 Whitney Avenue, New Haven, CT, 06511, USA.

Email: ross.anderson@yale.edu Telephone: +441159830786 or +16178003291

${ }^{2}$ School of Geography, Earth and Environmental Sciences, University of Birmingham, Edgbaston, Birmingham, B15 2TT, UK.

\section{Email: i.j.fairchild@bham.ac.uk}

${ }^{3}$ Department of Earth Sciences, Irvine Building, University of St Andrews, St Andrews, Fife, KY16 9AL, UK.

Email: njt6@st-andrews.ac.uk

${ }^{4}$ Department of Organismic and Evolutionary Biology, Harvard University, 26 Oxford Street, Cambridge, MA, 02138, USA.

Email: aknoll@oeb.harvard.edu

\section{ABSTRACT}

Microscopic spherules in relatively undeformed mudstones of the Neoproterozoic Bonahaven Formation, Islay, Scotland, are differentiated from their matrix by a sharp micron-scale, smoothly rounded boundary. These elongate spherules were earlier interpreted as hollow bodies filled penecontemporaneously by glauconite and subsequently metamorphosed to phengite, but their origin remains a matter of debate. Spherules observed in thin section are predominantly rounded ( $74 \%)$ but can exhibit a flat edge or protrusion at one end. In $11 \%$ of a sample population, two or more spherules are conjoined. X-ray diffraction indicates that spherulebearing mudstones consist mainly of muscovite, with variable amounts of kaolin-group minerals and minor iron-chlorites. A range of physical origins for the spherules -- including 
microconcretions or metamorphic microstructures; deposition from the sky as micrometeorites, microtektites/microkrystites, or voleanic lapilliaccretionary volcanic ash particles; and detrital grains - is considered but rejected on distributional, morphological, and mineralogical evidence. Biological origins are considered most likely, especially protistan tests similar to the vase-shaped microfossils found in somewhat older Neoproterozoic rocks. If correct, this provides the first report of eukaryotic life in the Dalradian succession that passes critical tests for biogenicity and new evidence for testate microfossils in post-Sturtian but pre-Marinoan aged rocks.

\section{KEYWORDS}

Biostratigraphy, Bonahaven Formation, Clay minerals, Neoproterozoic, Sturtian glaciation, Vase-shaped microfossils 


\section{Introduction}

Over the past two decades, paleontologists have documented diverse eukaryotic fossils in

Neoproterozoic rocks (Knoll et al., 2006). Despite their substantial thickness and extensive outcrop, however, Dalradian strata of Scotland have played little role in these discoveries, with the few existing reports being open to question (Brasier and Shields, 2000). Perhaps metamorphism has erased whatever microfossil record once existed in Dalradian strata. Or perhaps the fossils are there, hiding in plain sight.

With this possibility in mind, we re-examined micaceous spherules reported by Fairchild (1977) in moderately metamorphosed, but locally undeformed mudstones from the Dalradian Bonahaven Formation, exposed along the northeastern coast of the Isle of Islay. Fairchild (1977) hypothesized that these ca. $100 \mu \mathrm{m}$ spherules record microfossils filled penecontemporaneously with glauconite, later metamorphosed to the metamorphic mica phengite. Glauconite is known to form penecontemporaneously in the cavities of foraminiferans and other microfossils where a dysoxic environment is present (Bjerkli and Östmo-Saeter, 1973; Odin and Matter, 1981). The logic behind Fairchild's interpretation was as follows:

1. the spherules display a restricted size distribution consistent with a biological origin

2. the spherules appear to have collapsed next to desiccation cracks and hence were hollow at the time of sedimentation, and

3. spherule fillings protrude at the edges of spherule-bearing mudstone intraclasts eroded penecontemporaneously, demonstrating an early mineral fill.

If Fairchild's (1977) interpretation is correct, the spherules represent an important record of Neoproterozoic life in the Dalradian Supergroup. However, while microfossils molded internally by authigenic minerals provide a plausible interpretation for these microstructures, it is 
impossible to rule out physical alternatives on the basis of evidence marshaled by Fairchild (1977). The spherules could, in fact, have originated in three distinct ways. Firstly, they could have originated within the sediment or rock as microconcretions or metamorphic microstructures. Alternatively, they could have been deposited from the sky as micrometeorites, microtektites/microkrystites, or voleanic lapilliaccretionary volcanic ash particles. Or, they could have originated within the ocean as detrital particles or biological remains. We combine field, petrographical, and geochemical methods to describe the distributional, morphological, and mineralogical characteristics of the Bonahaven spherules and interpret their origin.

\section{$2 \quad$ Geological Setting}

The Neoproterozoic Era, was a critical period of environmental and biological transition, during which the Earth experienced several geographically widespread glaciations set in a framework of marked carbon cycle variation, while transiting from a microbial world to one containing metazoans (Erwin et al., 2011; Gaidos et al., 2007; Hoffman et al., 1998; Knoll, 2003; Macdonald et al., 2010; McCay et al., 2006). In Scotland and Ireland, much of the Neoproterozoic Era is represented by the Dalradian Supergroup, comprised of the Grampian, Appin, Argyll and Southern Highland Groups (oldest to youngest). The Dalradian basin's ca. $25.5 \mathrm{~km}$ composite thickness is dominated by diverse marine sandstones and mudstones, most of which have been metamorphosed to psammites, pelites, and phyllites, along with volcanic rocks emplaced later in its development.

There is currently little consensus on the tectonic history of the Dalradian basin. Through facies observation, Prave (1999) proposed that the earliest sediments (the Grampian Group through the Lochaber Subgroup) were probably deposited in a rapidly subsiding foredeep associated with the mid-Neoproterozoic Knoydartian Orogeny (840-730 Ma). Prave (1999) further suggested that deposition changed to a shelf or platform setting before a late 
Neoproterozoic Iapetan transition from rift to drift. This interpretation contrasts with that of Anderton (1982), who originally proposed a tectonic and sedimentary evolution through continuous extension associated with the breakup of the supercontinent Rodinia. With either hypothesis it is clear that extensional tectonics were an important contributor to upper Dalradian development.

Few radiometric dates constrain Dalradian sedimentation. The oldest sediments postdate basement dated by $\mathrm{U}-\mathrm{Pb}$ analysis of monazite to $806 \pm 3 \mathrm{Ma}$ (McCay et al., 2006). Close to its top, in the Southern Highlands Group, ash beds have yielded U-Pb zircon ages of $601 \pm 4 \mathrm{Ma}$ and $595 \pm 4$ Ma (McCay et al., 2006).

The Bonahaven Formation and its associated spherules are situated within the Argyll Group (Harris et al., 1994). The Group records two major glaciations. The Port Askaig Tillite, a $750 \mathrm{~m}$ succession of diamictites interbedded with sandstone, conglomerate and mudstone horizons, lies at the base of the Islay Subgroup, immediately below the Bonahaven Formation (Spencer, 1971). A distinctive negative carbon isotope anomaly combined with characteristically low ${ }^{87} \mathrm{Sr} /{ }^{86} \mathrm{Sr}$ values in carbonates below the Tillite points to a correlation with early Cryogenian (Sturtian) glaciation (Brasier and Shields, 2000; Sawaki et al., 2010). Higher in the Argyll Group, the Stralinchy Diamictite of Ireland has been correlated to the Marinoan Glaciation ( $\sim 635$ Ma) based on the observations of Prave et al. (2009), who reported rising $\delta^{13} \mathrm{C}_{\mathrm{V} \text {-PDB }}$ values in pre-glacial carbonates from $0 \%$ to $6 \%$, before a plunge to $-12 \%$ (Trezona carbon isotope anomaly) and subsequent recovery to $0-2 \%$ immediately beneath the diamictite. In contrast to these chemostratigraphic and sedimentological correlations, a Re-Os date of $659.6 \pm 9 \mathrm{Ma}$ for the Ballachulish Formation, which lies stratigraphically below Port Askaig beds, encourages an alternative interpretation in which the Port Askaig Tillite correlates with the Marinoan glaciation 
(Rooney et al., 2011). Since the Bonahaven lies stratigraphically above the Port Askaig deposits it must postdate Sturtian glaciation regardless of which stratigraphic interpretation is correct. The $300 \mathrm{~m}$ thick, largely dolomitic Bonahaven Formation crops out only on the Isle of Islay (Fairchild, 1985). Spencer and Spencer (1972) suggested a shallow subtidal to inter- and supra-tidal environment of deposition, citing as evidence the presence of stromatolites and subaerial mudcracks associated with mudflake breccias. Fairchild (1980), in turn, summarized the Bonahaven succession as recording a range of shallow sub-tidal to intertidal tide- and stormdominated settings. Bonahaven rocks were altered by greenschist facies (biotite-grade) metamorphism, reaching a maximum temperature of $<450{ }^{\circ} \mathrm{C}$ during the Ordovician-Silurian Caledonian orogeny (Fairchild, 1985). Despite this regional context, perhaps uniquely for pelitic rocks in the Dalradian, spherule-bearing localities display no metamorphic textures (silt-grade quartzo-feldspathic detritus is still recognizable) and have no discernible tectonic fabric (Fairchild, 1985, 1991; McCay et al., 2006).

The formation has been subdivided into four members (Fairchild, 1985, 1991). Spherules occur toward the top of Bonahaven member 1 in exposures near the coastal village of Bunnahabhain (Bonahaven), where the uppermost $6 \mathrm{~m}$ of the member are exposed beneath white sandstones (quartzites) of member 2. The local succession consists of millimetre- to centimetrescale interlaminations of dark carbonaceous mudstone and fine- to medium-grained sandstone. The sandstones consist mostly of moderately sorted, subangular quartz grains with a few percent feldspar, titanium-enriched iron oxides and elongate muscovite grains. The titanium-enriched iron oxides commonly occur in linear arrays that run sub-parallel to bedding and which are thought to be density concentrates during sedimentation. Cross-bedding occurs at several horizons and dolomitic cementation is seen locally. These dolomitic sandstones tend to have 
coarser quartz grains, with some reaching a millimetre in maximum dimension. Fairchild (1977) interpreted the Bunnahabhain section in terms of tidal flat deposition, possibly close to a barrier island. Both sub-aerial desiccation cracks and sub-aqueous syneresis cracks are present within the section, suggesting a very shallow environment, episodically exposed sub-aerially. Spherulebearing horizons are also exposed further south at Caol Ila where similar interlaminated sediments occur. In this second locality, however, mudstone beds are commonly not laterally continuous.

\section{$3 \quad$ Methods}

At the two field exposures, $\sim 1 \mathrm{~km}$ south of Bunnahabhain (NR 4235 7284) and Caol Ila (NR 4280 7024), stratigraphic sections were measured through the upper part of member 1 and samples collected within this framework. At Bunnahabhain 17 samples were collected, distributed throughout a vertical section of $6.07 \mathrm{~m}$; at Caol Ila 9 samples, distributed through 4.7 m. Eight previously collected samples were also linked to these measured sections.

Size measurements were taken for 1,530 spherules from the Bunnahabhain locality using optical microscopy on thin sections in transmitted light. Size distributions were corrected for cut effects using the numerical method of Hennig and Elias (1971). In order to ensure consistent manual measurement of diameters, measurements were repeated three times for 40 spherules, with a mean standard deviation among the three measurements of $3.5 \%$.

Scanning electron microscopy (SEM) analyses, including backscatter imaging, were conducted to identify spatial patterns of chemical composition. Elemental mapping using SEM was also conducted via energy dispersive X-ray spectroscopy (EDS) on two thin-sections from the Bunnahabhain locality. Elements were chosen in accordance with Fairchild's (1977) interpretation of phengite mineralogy, with the addition of several elements of potential paleobiological interest. Therefore we mapped aluminum, calcium, carbon, magnesium, oxygen, 
phosphorus, potassium, silicon, and sulfur. Nickel was also mapped, as it is characteristically associated with extraterrestrial deposits (Glass and Simonson, 2012; Grieve, 1991). Mapping was limited to sections in which spherules were present. EDS was additionally used to target specific spots on the thin-sections, commonly detrital grains identified from backscatter images.

X-ray diffraction (XRD) was performed to ascertain clay mineralogy present in bulk samples. Three samples from Bunnahabhain (BD004, BD008, BD014) and one from Caol Ila (CID008) were analyzed. BD004 was taken from a sandstone horizon with no spherules. BD008, BD014, and CID008 include sandstone and mudstone horizons, the latter containing spherules.

Data were acquired on $<2 \mu \mathrm{m}$ size fractions extracted from the samples (using methods outlined in Moore and Reynolds, 1997), and were prepared as oriented aggregates. Samples were analyzed in air-dried and glycerolated states, and again after heating for 2 hours at $400{ }^{\circ} \mathrm{C}$ to identify expandable components, as well as the presence of Fe-serpentine and/or chlorite phases.

\section{$4 \quad$ Spherules: defining characteristics}

\subsection{Stratigraphic distribution}

Spherules were observed only in samples from the top $4.5 \mathrm{~m}$ of member 1 . At

Bunnahabhain, they occur through $3.5 \mathrm{~m}$ of section (1.5-5 $\mathrm{m}$ from the base of the exposure) and at Caol Ila, they are found within the bottom $1 \mathrm{~m}$ of the exposure (Fig. 2). Notably, within these sections, spherules occur only in mudstone laminae and isolated mudstone pebbles; they are absent from interlaminated sandstones. At Bunnahabhain, $83 \%$ of sampled mudstone laminae contain spherules; at Caol Ila this figure rises to $100 \%$. Within the mudstones, spherules constitute some $\sim 40 \%$ of the rock by volume. The presence of spherules along the margins of mudstone pebbles reworked into quartz sandstones (Supp. Fig. 3) supports Fairchild's (1977) hypothesis that the spherules were mineralized penecontemporaneously. Moreover, in horizons 
where soft sediment deformation has contorted laminae, spherules follow original bedding, again suggesting early emplacement. In general, the long axes of spherules align with bedding; within the plane of lamination, however, orientations are essentially random.

\subsection{Morphological Characteristics}

In thin-section, the spherules range in maximum dimension from 35 to $310 \mu \mathrm{m}$, with the modal size category being $127-150 \mu \mathrm{m}($ mean $=138 \mu \mathrm{m})($ Fig. 5$)$. We observed no significant size variation among samples. Corrected for the under-sampling of maximum diameters, the size distribution shows no difference in modal class from the measured distribution but displays higher frequencies of spherules in the size classes that range from 150 to $242 \mu \mathrm{m}$.

Spherules are circular to ovoid in thin-section. Some, however, exhibit a flat surface at the tapering end of the long axis (Fig. 4 B-F), and in some specimens this takes the form of an irregularly shaped neck-like structure, $\sim 10 \mu \mathrm{m}$ in maximum length, that protrudes into the matrix (Fig. 4 B-C E-G). Spherules illustrated in Figure 4 G also show an indentation within their necks so that there appear to be two protrusion features in each, or an embayment created during burial compaction. It is also possible to observe conjoined spherules (Fig. $4 \mathrm{H}$ ) and deformed elliptical spherules with long-axes oriented parallel to desiccated margins (Supp. Fig. 4) (Fairchild, 1977). Notably, spherule interiors are separated from the mudstone matrix by a smoothly rounded boundary no more than a micrometre thick.

Several margins between mudstone and sandstone layers contain deformed spherules (Supp. Fig. 4). Nearing the desiccated margin, the spherules become elliptical, with their long axis parallel to the lamina margin. (4) - Critically this is seen also in bedding-parallel sections where the elliptical spherules parallel adjacent desiccation crack margins, showing the deformation was independent of burial compaction effects (Supp. Fig. 4 B). As Fairchild (1977) 
noted, the only possible explanation for this distributional phenomenon invokes the role of desiccation. Upon desiccation, the exposed mudstone lost water and compacted, with most severe and rapid shrinkage next to the exposed surface. Strain markers such as the emplaced spherules would record this compaction by flattening parallel to the desiccated margin. An additional observation supports the hypothesis that the structures were mineralized prior to compaction: matrix material can be seen to align to and drape over spherules (Fig. 4 D).

\subsection{Mineralogical Characteristics}

Clay minerals are prominent constituents of both the mudstone matrix and spherule interiors. In contrast, various detrital grains (EDS analysis suggests grains of apatite, titaniumenriched iron oxide and quartz) and dark materials (graphite and heavy minerals) that color the matrix are largely absent from spherule interiors. This contrast demonstrates that the spherule interior is not simply sediment matrix forced into spherule interiors. Rather, spherules were either solid entities or hollow structures filled by mineral precipitation during early diagenesis. The latter view is supported by spherules in which a bit of matrix extends into their interior or in which low densities of graphite occur (Fig. 4 B). As noted by Fairchild (1977), some spherules display a broad orientation of crystallites perpendicular to walls light, especially along their outer margins-(Fig. 4 F; see also Fairchild (1977) plate 1).

XRD analysis of the $<2 \mu \mathrm{m}$ fraction extracted from bulk rock samples (Fig. 6) indicates that the spherule-bearing mudstone consists largely of muscovite of the 2M1 polytype. However, the differences between the rather common muscovite 2M1 structure and the far less abundant phengite 2M1 structure (phengite is much more commonly found in the 1M structure; see Bailey, 1980) are subtle, and so we cannot rule out appreciable Mg and/or Fe substitution in muscovite that would render this phase phengitic. There is also a variable amount of kaolin-group minerals 
in the samples, as displayed by the variation in peak intensity at $\sim 7.10 \AA$ and $3.56 \AA$. Depending on the temperature to which the Bonahaven Formation was subjected during metamorphism, these could represent kaolinite or dickite (Weaver, 1989). Biotite may be present in small amounts but it is not a major component. Analysis after heating to $400{ }^{\circ} \mathrm{C}$ shows measureable decreases in the intensity of peaks indicative of Fe serpentine/Fe-chlorite minerals such as berthierine or chamosite, which are likely of early diagenetic origin or associated with greenschist-facies metamorphism. The abundance of these phases compared to muscovite is relatively low which reflects abundances in the $<2 \mu \mathrm{m}$ extracted from the whole rock. It might not be surprising that these metamorphosed mudstones should contain Febearing muscovite and chlorite; increasingly, analyses show that carbonaceous shales of the later Neoproterozoic Era are commonly enriched in highly reactive Fe, sourced from ferruginous water masses (Canfield et al., 2008; Johnston et al., 2010). As the Bonahaven member 1 is interpreted as a coastal deposit, Fe-oxides may also have been introduced from continental sources. Potential precursor minerals for the metamorphic Fe-bearing muscovite include Febearing smectites, which, in marine settings, are thought to form through the addition of Fe to pre-existing detrital substrates under poorly-oxygenated to anoxic conditions (Meunier and El Albani, 2007). Spherules do not stand out in elemental maps using EDS, suggesting no differential enrichment of elements within spherules (Supp. Fig. 1).

\section{Discussion}

As noted above, the Bonahaven spherules could, in principle, have formed from the sky, in the ocean, or within the sediments themselves. Observations of stratigraphic distribution, morphology, and mineralogy, however, sharply constrain interpretation of these distinctive structures. 


\subsubsection{Origin from the Sky}

The spherules might have an extraterrestrial origin, as micrometeorites ${ }_{2}$-or microtektites, or microkrystites. Micrometerorites are small particles of cosmic origin (Onoue et al., 2011).

Each year 30,000 tonnes are captured by the Earth, with $90 \%$ being destroyed upon entry (Onoue et al., 2011). As such, discoveries of micrometeorites are rare and are confined to rocks younger than the Jurassic Period (Onoue et al., 2011). Micrometeorites are on the order of tens of microns in linear dimension, making them broadly comparable to the spherules of Fairchild (1977).

However, micrometeorites are solid remains with a silicate or iron composition and distinct nickel enrichment. EDS elemental mapping analysis shows that the Bonahaven spherules are not significantly enriched in nickel and indeed reveal no mineralogical features consistent with their interpetation as micrometeorites.

Unlike micrometeorites, microtektites and microkrystites are rounded glass spherules originating from the splash debris of a bolide impact (Glass and Simonson, 2012; Kirkham, 2003; Simonson, 2003). They are famously associated with the Cretaceous-Paleogene boundary (Montanari et al., 1983) and have been identified in rocks as old as Archean (Simonson, 2003). Microtektites-These ejecta vary markedly in size and shape, including spheroids, elongate structures, flanged spheroids or discs, spindle-shaped forms, and dumbbells (Glass and Simonson, 2012). Breakage of barbell-shaped structures can result in elongated spheroids with truncated neck-like extensions (e.g. Bunch et al., 2012). Thus, such impact ejectamicrotektites command attention as a possible explanation for the Bonahaven spherules. 
and at least some similarities are only superficial. For example, the Bonahaven population includes no true dumbell-shaped individuals; where two flask-shaped individuals are conjoined, the individuals are commonly separated by a thin intervening wall of matrix materials, and neither conjoined spherules nor flask-shaped individuals exhibit the curvature associated with microtektites-ejecta shaped by viscous material in motion (e.g. Bunch et al., 2012). Additionally microtektites commonly show evidence of an outer crust, often cracked, with radially growing erystals (Kirkham, 2003). This crust is not seen on the Bonahaven spherules, which are differentiated from the mudstone matrix by their micron-thick boundaries. Mineralogically microtektites are commonly enriched in platinum-group elements such as nickel (Glass and Simonson, 2012; Grieve, 1991), a feature not observed in Bonahaven spherules, although arguably oblitated during metamerphism.

The most compelling argument against an extraterrestrial origin, however, comes from distributional characteristics. As noted previously, Bonahaven spherules (1) occur through several meters of stratigraphy, and (2) are confined to mudstones. Like the Bonahaven population, microtektites/microkrystites can be distributed through several meters of stratigraphy (Glass and Simonson, 2012). The reason for this, however, is not that microtektites/microkrystites rain down on the seafloor more or less continuously for thousands of years but rather that sedimentary processes can rework microtektites-ejecta formed by a single impact. This is where observation 2 assumes importance. We have observed no grain-supported spherule populations; all spherules "float" in a mudstone matrix. No spherules have been observed in sandstone horizons through the interval in question. Thus, if the spherules are reworked, they must have had a mass closer to associated clay particles than to sand grains and so could not in principle have been made of silicate minerals. In combination, then, the 
morphological, mineralogical, and distributional characters of the Bonahaven spherules seem to preclude an origin as microtektites/microkrystites.

One additional potential origin from the sky is as volcanic accretionary tapilli-particles -coarse-grained ash ejected from a volcanic source (ash cloud or pyroclastic flow) (Schumacher and Schmincke, 1991; Tucker, 2001). The type that appear most similar to the Bonahaven spherules are termed lapilli. Lapilli are spherical or ellipsoidal in shape and are definied as being 2-64 $\mathrm{mm}$ in maximum dimension although commonly include much smaller grains (Gernon et al., 2012). Spherical or ellipsoidal in shape, they are on the order of $2 \mathrm{~mm}$ maximum dimension and are associated with event deposits of ash clouds and pyroclastic flows (Schumacher and Schmincke, 1991; Tucker, 2001). Lapilli generally have an enveloping rim composed of concentric rings of ash which become progressively finer in grain size or which alternate between fine and very fine sized grains (Schumacher and Schmincke, 1991). Interpretation of Bonahaven spherules as lapilli encounters the same problem as microtektite/microkrystite proposals: all spherules float in a fine-grained matrix, with few grain-grain spherule contacts, and spherules are conspicuously absent from sandstones population of quartz grains. Moreover, the spherules show neither structural eviddience for concentric accretion nor eviddience of originally volcanic mineralogy.

\subsubsection{Secondary Origin}

Perhaps, instead, the Bonahaven spherules originated within their matrix, during diagenesis or metamorphism. During diagenesis, authigenic minerals could form microconcretions with broadly spheroidal morphology; moreover, microconcretions might develop preferentially in mud matrices. It is less clear, however, why microconcretions would have such a sharply constrained size distribution through their stratigraphic distribution and 
across localtities. Nor is it obvious why the spherules should have such regular, smoothly curved boundaries, neck-like extensions or aperture-like truncations. The oriented crystal fabric originally observed by Fairchild (1977) is also problematic, in that it suggests nucleation along the bounding walls of the spherules and inwardly directed growth -- likely if mineral precipitates nucleated on a wall and grew into empty space, but not if they were accreting concretions. For these reasons, we doubt that the Bonahaven spherules represent microconcretions. Contact metamorphism adjacent to igneous intrusions can give rise to metamorphic spots/clots, and a Cenozoic dolerite dyke is present to the south of the Bunnahabhain outcrops. Metamorphic spots are often millimetre scale and generally consist of muscovite and chlorite aggregates (Bucher and Grapes, 2011; Cruz and Galan, 2002). While the bulk mineralogy of the Bonahaven spherules is compatible with such an origin, they do not exhibit the expected morphology. The spherules are at least five times smaller than most described metamorphic spots and do not exhibit the same colour gradation as the spots documented by Cruz and Galan (2002). Moreover, while some mudstone horizons contain spherules, others do not - an unexpected observation if metamorphism formed the spherules. Finally, metamorphic spots/clots do not have sharp margins but are superimposed on the exisiting rock fabric with an irregular boundary (Bucher and Grapes, 2011; Cruz and Galan, 2002). The Bonahaven spherules are clearly differentiated from the matrix, having a micron-thick, smoothly rounded boundary. Similar metamorphic clots of higher grade composed of biotite can be eliminated through mineralogical data, as biotite is absent from bulk XRD analysis. Spherules within mudstone pebbles locally protrude slightly into encompassing sandy laminae, indicating that these spherules were at least partly mineralised prior to erosion, sand deposition and subsequent lithification (Fairchild, 1977). 
This casts still more doubt on a metamorphic origin, as does the apparent shrinkage of spherules parallel to desiccation margins.

\subsubsection{Origin from the Ocean}

The final potential source for the spherules is the surrounding ocean. An origin as terrigenous detritus can be dismissed as follows. Detritus is observed throughout the mudstone in the mineralogical form of apatite, feldspar, titanium-enriched iron oxides, and quartz, each on the order of a few microns in linear dimension, with occasional grains reaching $40 \mu \mathrm{m}$-- much smaller than maximum grain size in interlaminated sandstones. The spherules do not have a mineralogical composition similar to those of unambiguous detrital grains, and they are evenly rounded, unlike subangular detritus. Moreover, the spherules possess few distributional features characteristic of detrital grains; spherules are restricted to mudstone horizons and are much larger than encompassing silicate grains. Furthermore, were they restricted by facies, detrital spherules would be unlikely to sort mechanically with the mud due to difference in volume and mass between the two. Hydrodynamically, then, the spherules are out of place in the mudstones, unless they were hollow.

Fairchild (1977) considered a further origin from the oceans: replacement of fecal pellets. There is, however, no confirmed evidence that macroscopic metazoans existed at the time of deposition. Nor would fecal pellets show the range of morphologies displayed in the Bonahaven spherules. Moreover, the collapse of spherules next to desiccated margins indicates they were not initially solid objectspreservation of radially oriented erystals within spherules suggests precipitation into a void.

\subsection{Biological Origin}


Having dismissed potential physical origins, we return to Fairchild's (1977) original paleobiological interpretation. A problem with the fossil-infill hypothesis, particularly at the time it was proposed, is that most Neoproterozoic microfossils of appropriate size are mechanically weak and collapse to essentially two-dimensional compressions in mudstone matrices (e.g., Knoll, 1996). Three-dimensionally preserved fossils filled with authigenic chert are known from micrites, but they have irregular shapes that document compression prior to silica emplacement (Knoll et al., 1991). The exception is vase-shaped microfossils, elongate tests originally discovered in 1933 and rediscovered the year Fairchild reported on the Dalradian microstructures (Bloesser et al., 1977). Interpreted as the tests of amoebozoans and rhizarians based on exceptionally preserved $\sim 742$ Ma examples from carbonate nodules in basinal shales two meters below a $742 \pm 6 \mathrm{Ma}$ ash bed in the uppermost $\Theta$ the Chuar Group, Grand Canyon (Porter and Knoll, 2000; Porter et al., 2003), vase-shaped fossils are widely distributed in ca. 800-740 Ma rocks, where they are routinely preserved three-dimensionally in fine-grained lithofacies as mineral-infilled casts and molds with no trace of original wall material (Porter and Knoll, 2000, and references therein). Their shape preserved due to the mechanical strength of vase walls, these tests were cast and infilled prior to significant compaction and before organic decay proceeded to completion. Like other coeval VSMs, the Chuar Group microfossils are cup- to tear-shaped tests that appear circular in transverse section and taper toward a single opening at one end while rounding or flaring to an aboral pole at the other (Porter and Knoll, 2000). Their size ranges from 25-160 $\mu \mathrm{m}$ in length and $15-105 \mu \mathrm{m}$ in width, with length to width ratos between $1: 1$ and 3:1. The majority are radially symmetric; however, around $25 \%$ are bilaterally symmetric with a curved neck. The neck is thought to represent an aperture and is between 5-40 $\mu \mathrm{m}$ maximum cross-sectional dimension (Porter and Knoll, 2000). Some Chuar Group VSMs also preserve a 
record of the organic wall as early diagenetic pyrite 1-3 $\mu$ m thick (Porter and Knoll, 2000), but in most occurrences all traces of the actual wall have been lost to decay (Knoll and Calder, 1983).

$$
\text { Bonahaven spherules possess many of the morphological and distributional features }
$$

noted for vase-shaped microfossils, including shape, size frequency distribution, and preservational mode. Distributionally, we know the Bonahaven spherules are restricted to mud laminae and isolated mud pebbles. Similarly, VSM assemblages are documented from carbonate and shale successions but not grainstones, likely because their tests decayed too rapidly for preservation in coarser sediments (Knoll, 1996; Porter and Knoll, 2000). In terms of size the Bonahaven spherules are broadly similar to Chuar Group VSMs, although the Chuar assemblage contains more specimens under $70 \mu \mathrm{m}$ long. We can also compare the vase-like shape. The best documented morphological feature of VSMs is their oral aperture, preserved as a neck structure (Porter and Knoll, 2000; Porter et al., 2003). Noting that modern testate protists vary widely in morphology, we can still ask whether Bonahaven spherules also preserve this feature. A majority do not, but then the aperture is not apparent in most Chuar VSMs observed in thin section. The reason for this is that the plane of section is more or less randomly oriented with respect to the test morphology, and many sections cut obliquely across tests, missing the aprerture. To compare unambiguous VSM populations observed in thin section with the Bonahaven spherules, we counted sample populations of Bonahaven spherules, Chuar Group VSMs (Porter and Knoll, 2000), and VSMs from the Draken Formation, Svalbard (Knoll et al., 1991), assigning individuals to one of four shape categories: rounded, rounded with a flat edge, rounded with protruding aperture structure, and conjoined.

Figure 8 highlights the similarity in shape distribution among the three sets of specimens, with each showing at least $74 \%$ rounded specimens and low values for specimens 
411 with protruding necks $(\sim 3 \%)$. The only major difference between the Bonahaven spherules and the unambiguous VSMs is that the Bonahaven spherules have a higher proportion of conjoined specimens: $11 \%$ compared to the $2 \%$ and $1 \%$ we observed in the Chuar Group and Draken Formation, respectively. Conjoined VSMs mierofessils-in the Uinta Group, which is correlative to the fossiliferous Chuar succession, were interpreted by Porter et al. (2003) as documenting asexual reproduction of testate amoebae (Fig. 9). During mitotic cell division, the daughter and mother cells remain attached at the aperture until division is complete (Porter et al., 2003). The higher proportion of conjoined specimens in the Bonahaven spherules might suggest that the fossilization process captured more specimens in reproductive mode. However, it might just be that the subsequent metamorphism brought some specimens into close contact.

If we remove the conjoined specimens from our analysis (Fig. 8) the Bonahaven spherules are distributed in exactly the same proportions as the Chuar VSMs and are similar to those of the Draken Formation. We can therefore infer that the preserved test structure has a similar distribution of oblique cross-sections in each assemblage, and thus the Bonahaven oblique sections capture the distinguishing morphological feature of VSMs, the aperture, to the same extent as those taken from rocks containing unambiguous VSMs. Such similarities in morphological features and facies-restricted preservation between the Bonahaven spherules and the broad class of testate organisms represented by the VSMs, support interpretation of the Bonahaven spherules as biological, and more specifically as penecontemporaneous internal molds of structurally rigid walls such as those found in Neoproterozoic VSMs and living testate amoebae. The broad radial fabrieorientation of crystallites perpendicular to walls observed in some spherule interiors is consistent with nucleation of infilling prepitates on the internal surfaces of test walls later obliterated by organic decay. 
Summing available observations of morphology, chemistry and stratigraphic distribution

- and acknowledging remaining uncertainties -- we propose the following explanation for the Bonahaven spherules:

1 Testate microorganisms lived in the local environment represented by Bonahaven siliciclastics: a shallow tidal setting likely close to a barrier island.

2 Upon death, evacuated tests were deposited from suspension along with muddy sediments.

3 Localized strong shrinkage of the mudstone caused by desiccation led to collapse and hence elongation of spherules adjacent to desiccated margins.

4 Penecontemporaneously, an iron-enriched mineral filled in the tests. We can eliminate a mechanical in-fill by surrounding mud sediments as there is a contrast in abundance of detrital and carbonaceous grains between the spherule interior and mudstone matrix. The evidence for iron enrichment comes from the bulk mineralogy suggested by XRD analysis. The iron-enriched muscovite and minor iron-serpentine/iron-chlorite observed today likely arose as metamorphic products of an iron-enriched precursor during Caledonian orogenesis. An iron-bearing smectite is thought to be the most likely precursor mineral (Meunier and El Albani, 2007). Infilling minerals grew centripetally from the perimeter wall of the test, giving rise to the radiat-orientation of crystallites s-observed in spherule interiors under cross-polarized light (Fig. 4 F; see also Fairchild (1977) plate 1).

5 Following in-filling of the cavity or lithification of the surrounding mudstones, the organic wall decayedlithification there was erosion of the sediments, creating the 
intraclasts of mudstones observable today. Also, at this point the spherules are already mineralized as evidenced by spherules protruding from the intraclasts.

6 Subsequent tectonic deformation and metamorphism during the Caledonian Orogeny and later plate movements subjected the rocks to temperatures possibly up to $450{ }^{\circ} \mathrm{C}$ and pressures less than 8 kbar, based on regional context (Fairchild 1977) and minerals characteristic of the greenschist metamorphic facies. As a result the bulk mineralogy changed to muscovite (potentially phengitic) of the $2 \mathrm{M} 1$ polytype, as observed by $\mathrm{XRD}$ analysis. At some point during this process the organic wall of the organism decayed and was not preserved. We do not know when this occurred, but an intact wall would have been required to sustain the three dimensional morphology of the test at least until encompassing sediments became lithified and/or the mold became infilled by minerals.

\section{$7 \quad$ Implications for the Record of Neoproterozoic Life}

The identification of the Bonahaven spherules as microfossils broadly similar to testate protists preserved in of the Chuar Group and correlative rocks provides two new perspectives on Neoproterozoic eukaryotic life. Firstly, it provides a record of protists in the Dalradian Supergroup, where few fossils have previously been documented. Brasier and Shields (2000) reported no eukaryotic micro- or macrofossils in Dalradian rocks of Neoproterozoic age and suggested that all previously proposed evidence, including possible trace fossils and macrofossils of Ediacaran faunas, can be attributed to physical origins.

The second perspective is that testate protists lived in coastal oceans between Neoproterozoic Snowball Earth events (Hoffman et al., 1998; Macdonald et al., 2010). The evolutionary impact of Neoproterozoic ice ages remains poorly known, in part because few 
microfossils are documented from rocks deposited between the two principal glaciations (Knoll et al, 2006; Macdonald et al., 2010). VSM taxa preserved in the Chuar and Draken assemblages have been found only in rocks deposited before the Sturtian glaciation, with the exception of some reported from the Kingston Peak Formation, Death Valley that are potentially synglacial in age (Corsetti et al., 2003; Licari, 1978; Walker et al., 1986). If chemo- and lithostratigraphic assignment of the Port Askaig Tillite to the Sturtian ice age is correct, then the Bonahaven Formation lies within the between-glacial interval (Brasier and Shields, 2000). As noted previously, the Re-Os date for the Ballachulish Formation of $659 \pm 9 \mathrm{Ma}$ (Rooney et al., 2011) calls into question this stratigraphic correlation, but even if we accept this date and reinterpret the Port Askaig as Marinoan, the Bonahaven spherules would postdate the Sturtian glaciation and so be younger than Chuar and correlative VSMs.

Recently, Bosak et al. (2012) interpreted small tubular structures from post-Sturtian cap carbonates of the Rasthof Formation, Namibia, as microfossils with affinities to modern singlechambered, agglutinated foraminiferans. Also, Bosak et al. (2011) reported agglutinated tests from Namibia and Mongolia, which they attributed to lobose testate amoebae and, perhaps, other heterotrophic protists. However one interprets the microstructures of Bosak et al. (2011), they do not record the same types of testate protists as those found so abundantly in pre-Sturtian rocks. Pre-Sturtian aged VSMs are attributed-compared mostly withte the lobose testate amoebae families Arcellidae, Trygonopyxidae, Difflugiidae, Hyalosphenidae, and Lesquereusiidae (Porter et al., 2003). In contrast the Rasthof Formation contains structures attributed to lobose testate amoebae families Heloperidae, Plagiopyxidae, and Difflugiidae, identified by aperture affinities to modern amoebozoans (Bosak et al., 2011). One may then ask whether the Bonahaven spherules, being post-Sturtian in age, are more similar in morphology to the VSMs-testate 
microfossils of Bosak et al. (2011) than to those VSMs from pre-Sturtian strata. The VSMs

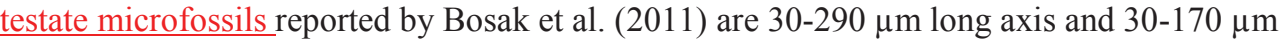
wide. In contrast, only $4 \%$ of the Bonahaven specimens measured in thin-section are larger than $190 \mu \mathrm{m}$ in maximum dimension. Yet they are not as small as the pre-Sturtian VSMs and so likely sit between the two assemblages in size. In terms of morphology the Bonahaven specimens resemble unambiguous pre-Sturtian VSMs (Fig. 8), but do not belong to the same taxa as these earlier counterparts. Finally, there are no visible concentrations of grains along spherule boundaries and so no evidence that the Bonahaven spherules possessed agglutinated tests like the

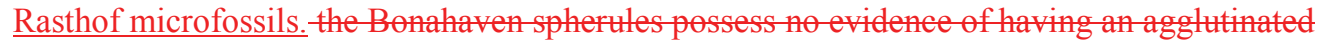
test like the Rasthof VSMs, with no visible concentration of grains along the spherule boundary, suggesting the spherules rather possessed an organic test that has since decayed. Consequently, their size, shape, and wall characteristics make it unlikely that the Bonahaven spherules are comparable to the populations reported by Bosak et al. (2011). Instead, despite their considerable age difference, they are broadly similar to pre-Sturtian assemblages, with possible affinities to the extant testate amoeban families Nebelidae, Hyalosphenidae, and Difflugiidae (Lahr, personal communication, 2012). Other vase-like microfossils have been described from younger sediments; however, these are thought to represent quite different taxa. For example, Hua et al. (2010) report VSMs larger in size $(600-2400 \mu \mathrm{m})$ from the Ediacaran Dengying Formation (551-541 Ma) thought to be associated with foraminifera. VSMs are not seen again until at least the Carboniferous Period (Wightman et al., 1994).

\section{Conclusions}

Microscopic spherules first described and interpreted as glauconitized microfossils by Fairchild (1977) are here interpreted as the metamorphosed casts and molds of testate amoebae 
526 broadly comparable to those well documented from pre-Sturtian assemblages. Distributional,

527 morphological, and mineralogical features are shared by both the Bonahaven spherules and

528 unambiguous VSM assemblages. It is inferred from XRD analyses that the organic-walled tests

529 were in-filled penecontemporaneously to sedimentation with an iron-bearing mineral (probably

530 smectite) before the wall was lost to decay. Iron is hypothesized to have been sourced either

531 from local ferruginous Neoproterozoic water masses or from the geographically proximal

532 continents. If correct, the Bonahaven spherules provide the first record of eukaryotic life within

533 the Dalradian Supergroup of Scotland. They also furnish an example of VSMs broadly similar to

534 those observed in the pre-Sturtian Chuar Group and Draken Formation, but separated from these

535 older deposits by (minimally) Sturtian glaciation.

536 


\section{ACKNOWLEDGMENTS}

Research leading to this paper was supported in part by the NASA Astrobiology Institute. Field work funding provided by the Harvard Origins of Life Initiative 2011 Summer Undergraduate Research Fellowship and the Department of Earth and Planetary Sciences, Harvard University.

This work was performed in part at the Center for Nanoscale Systems (CNS), a member of the National Nanotechnology Infrastructure Network (NNIN), which is supported by the National Science Foundation under NSF award no. ECS-0335765. CNS is part of Harvard University.

We thank David Johnston, Daniel Lahr, and Bruce Simonson for providing constructive comments and insights into the realms of geochemistry, modern testate microorganisms, and impact spherules respectively.

We thank Phoebe Cohen for assistance in operating the SEM, and Emily Macmillan and Edward Fleming for assistance in the field and at the University of Birmingham.

\section{APPENDIX}

Supplementary Figure 1: Scanning electron microscopy analysis of thin-section PB-I14 using back-scatter and EDS elemental mapping techniques. Scale bar is $200 \mu \mathrm{m}$. Sample level can be obtained from Figure 2. Analyses conducted using SUPRA 55VP-30-48 348x EHT $15.05 \mathrm{kV}$ at the Harvard Center for Nanoscale Systems. Top Left: Back-scatter image of mudstone horizon containing spherules showing an example spherule outlined in red, other spherules denoted by lack of detritus. Above: Microprobe elemental density maps showing general homogeneity across the thin-section. Bottom Right: Location of analysis depicted on flat-bed scan of thinsection.

Supplementary Figure 2: EDS analysis of mudstone horizon within thin-section BD013B showing characteristic elemental peaks. All scale bars are $100 \mu \mathrm{m}$. Sample level can be obtained from Figure 2. Analyses conducted using SUPRA 55VP-30-48 $20 \mathrm{kV}$ amp 25 at the Harvard Center for Nanoscale Systems. A: Back-scatter image showing target location for matrix. B: Elemental composition of matrix showing characteristic elements of muscovite. C: Back-scatter image showing target grain for D. D: Elemental composition characteristic of quartz. E: Backscatter image showing target grain for F. F: Elemental composition characteristic of titaniumenriched iron oxide. G: Back-scatter image showing target grain for H. H: Elemental composition characteristic of apatite. 
Supplementary Figure 3: Photomicrographs of thin-sections showing Bonahaven spherules in a mudstone intraclast penetrating sandstone interlaminations and sometimes truncating at the margins. Coordinates reported for England Finder with thin-section orientated so that fixed corner is next to thin-section label. Scale given in images. A: Image courtesy Fairchild (1977). B: $485332 \mathrm{U} 45 / 0$.

Supplementary Figure 4: Collapsed spherules next to desiccated margins. Coordinates reported for England Finder with thin-section orientated so that fixed corner is next to thin-section label. A: Photomicrograph of desiccated mud margin in bedding perpendicular thin-section showing spherules elongated with long axis parallel to desiccated margin. Scale bar is $300 \mu \mathrm{m}$. B: Photomicrograph of desiccated mud margin in bedding parallel thin-section showing spherules elongated with long axis parallel to desiccated margin, $485332 \mathrm{R} 28 / 4$. Scale bar is $300 \mu \mathrm{m}$. C: Drawing of bedding perpendicular thin-section showing spherule bearing mudstone horizons and desiccated areas. Images A and C courtesy Fairchild (1977).

\section{REFERENCES}

Anderton, R., 1982. Dalradian Deposition, the Late Precambrian-Cambrian History of the N Atlantic Region and the Early Evolution of the Iapetus Ocean. J. Geol. Soc. 139, 222-222.

Bailey, S.W., 1980. Structures of Layered Silicates, in: Brindley, G.W., Brown, G. (Eds.), Crystal Structures of Clay Minerals and Their X-Ray Identification. Mineralogical Society, London, pp. 1-124.

Bjerkli, K., Östmo-Saeter, J.S., 1973. Formation of Glauconite in Foraminiferal Shells on Continental-Shelf Off Norway. Marine Geology 14, 169-178.

Bloeser, B., Schopf, J.W., Horodyski, R.J., Breed, W.J., 1977. Chitinozoans from Late Precambrian Chuar Group of Grand-Canyon, Arizona. Science 195, 676-679.

Bosak, T., Lahr, D.J.G., Pruss, S.B., Macdonald, F.A., Dalton, L., Matys, E., 2011. Agglutinated Tests in Post-Sturtian Cap Carbonates of Namibia and Mongolia. Earth and Planetary Science Letters 308, 29-40.

Bosak, T., Lahr, D.J.G., Pruss, S.B., Macdonald, F.A., Gooday, A.J., Dalton, L., Matys, E.D., 2012. Possible Early Foraminiferans in Post-Sturtian (716-635 Ma) Cap Carbonates. Geology 40, $67-70$.

Brasier, M.D., Shields, G., 2000. Neoproterozoic Chemostratigraphy and Correlation of the Port Askaig Glaciation, Dalradian Supergroup of Scotland. J. Geol. Soc. 157, 909-914.

Bucher, K., Grapes, R., 2011. Petrogenesis of Metamorphic Rocks, 8 ed. Springer, Berlin.

Bunch, T.E., Hermes, R.E., Moore, A.M.T., Kennett, D.J., Weaver, J.C., Wittke, J.H., DeCarli, P.S., Bischoff, J.L., Hillman, G.C., Howard, G.A., Kimbel, D.R., Kletetschka, G., Lipo, C.P., Sakai, S., Revay, Z., West, A., Firestone, R.B., Kennet, J.P., 2012. Very High-Temperature Impact Melt Products as Evidence for Cosmic Airbursts and Impacts 12,900 Years Ago. Proceedings of the National Academy of Sciences of the United States of America 109, E1903E1912. 
Callegari, E., Pertsev, N.N., 2007. Contact Metamorphic Rocks.

Canfield, D.E., Poulton, S.W., Knoll, A.H., Narbonne, G.M., Ross, G., Goldberg, T., Strauss, H., 2008. Ferruginous Conditions Dominated Later Neoproterozoic Deep-Water Chemistry. Science 321, 949-952.

Corsetti, F.A., Awramik, S.M., Pierce, D., 2003. A Complex Microbiota from Snowball Earth Times: Microfossils from the Neoproterozoic Kingston Peak Formation, Death Valley, USA. Proceedings of the National Academy of Sciences of the United States of America 100, 43994404.

Cruz, M.D.R., Galan, E., 2002. Mineralogy and Origin of Spots in Spotted Slate from the Malaguide Complex, Betic Cordilleras, Spain: An XRD, EMPA and TEM-AEM Study. Canadian Mineralogist 40, 1483-1503.

Dressler, B.O., Reimold, W.U., 2001. Terrestrial Impact Melt Rocks and Glasses. Earth-Science Reviews 56, 205-284.

Elliston, J., 1968. Retextured sediments. XXIII Int. geol. Cong. 8, 85-104.

Erwin, D.H., Laflamme, M., Tweedt, S.M., Sperling, E.A., Pisani, D., Peterson, K.J., 2011. The Cambrian Conundrum: Early Divergence and Later Ecological Success in the Early History of Animals. Science 334, 1091-1097.

Fairchild, I.J., 1977. Phengite Spherules from Dalradian Bonahaven Formation, Islay, Scotland Glauconitized Microfossils. Geological Magazine 114, 355-364.

Fairchild, I.J., 1980. Stages in a Precambrian Dolomitization, Scotland - Cementing Versus Replacement Textures. Sedimentology 27, 631-650.

Fairchild, I.J., 1985. Petrography and Carbonate Chemistry of Some Dalradian Dolomitic Metasediments - Preservation of Diagenetic Textures. J. Geol. Soc. 142, 167-185.

Fairchild, I.J., 1991. Itinerary Ii: Topmost Islay Limestone (Appin Group), Port Askaig and Bonahaven Formations (Argyll Group) Port Askaig Area, Islay, in: Hambrey, M.J., Fairchild, I.J., Glover, B.W., Stewart, A.D., Treagus, J.E., Winchester, J.A. (Eds.), Geologists's Assocation Guide No. 44: The Late Precambrian Geology of the Scottish Highlands and Islands. The Geologists' Association, London.

Gaidos, E., Dubuc, T., Dunford, M., McAndrew, P., Padilla-Gamino, J., Studer, B., Weersing, K., Stanley, S., 2007. The Precambrian Emergence of Animal Life: A Geobiological Perspective. Geobiology 5, 351-373.

Gernon, T.M., Brown, R.J., Tait, M.A., Hincks, T.K., 2012. The origin of pelletal lapilli in explosive kimberlite eruptions. Nature Communications 3 , Article Number: 832, DOI: $\underline{10.1038 / \text { ncomms } 1842 .}$

Glass, B.P., Simonson, B.M., 2012. Distal Impact Ejecta Layers: Spherules and More. Elements 8, 43-48.

Grieve, R.A.F., 1991. Terrestrial Impact - the Record in the Rocks. Meteoritics 26, 175-194. 
Harris, A.L., Haselock, P.J., Kennedy, M.J., Mendum, J.R., 1994. The Dalradian Supergroup in Scotland, Shetland and Ireland., in: Gibbons, W., Harris, A.L. (Eds.), A Revised Correlation of Precambrian Rocks in the British Isles. The Geological Society, Bath, pp. 33-53.

Hennig, A., Elias, H., 1971. Rapid Method for Visual Determination of Size Distribution of Spheres from Size Distribution of Their Sections. J. Microsc.-Oxf. 93, 101-\&.

Hoffman, P.F., Kaufman, A.J., Halverson, G.P., Schrag, D.P., 1998. A Neoproterozoic Snowball Earth. Science 281, 1342-1346.

Hua, H., Chen, Z., Yuan, X., Xiao, S., Cai, Y., 2010. The Earliest Foraminifera from Southern Shaanxi, China. Science China-Earth Sciences 53, 1756-1764.

Johnston, D.T., Poulton, S.W., Dehler, C., Porter, S., Husson, J., Canfield, D.E., Knoll, A.H., 2010. An Emerging Picture of Neoproterozoic Ocean Chemistry: Insights from the Chuar Group, Grand Canyon, USA. Earth and Planetary Science Letters 290, 64-73.

Kirkham, A., 2003. Glauconitic Spherules from the Triassic of the Bristol Area, SW England: Probable Microtektite Pseudomorphs. Proceedings of the Geologists Association 114, 11-21.

Knoll, A.H., 1996. Archean and Proterozoic Paleontology, in: Jansonius, J., McGregor, D.C. (Eds.), Palynology: Principles and Applications. Publishers Press, Utah, pp. 51-80.

Knoll, A.H., 2003. Life on a Young Planet: The First Three Billion Years of Evolution on Earth. Princeton University Press, Princeton.

Knoll, A.H., Calder, S., 1983. Microbiotas of the Late Precambrian Rysso Formation, Nordaustlandet, Svalbard. Palaeontology 26, 467-496.

Knoll, A.H., Javaux, E.J., Hewitt, D., Cohen, P., 2006. Eukaryotic Organisms in Proterozoic Oceans. Philosophical Transactions of the Royal Society B-Biological Sciences 361, 1023-1038.

Knoll, A.H., Swett, K., Mark, J., 1991. Paleobiology of a Neoproterozoic Tidal Flat Lagoonal Complex - the Draken Conglomerate Formation, Spitsbergen. Journal of Paleontology 65, 531570.

Licari, G.R., 1978. Biogeology of Late Pre-Phanerozoic Beck Spring Dolomite of Eastern California. Journal of Paleontology 52, 767-792.

Macdonald, F.A., Schmitz, M.D., Crowley, J.L., Roots, C.F., Jones, D.S., Maloof, A.C., Strauss, J.V., Cohen, P.A., Johnston, D.T., Schrag, D.P., 2010. Calibrating the Cryogenian. Science 327, 1241-1243.

McCay, G.A., Prave, A.R., Alsop, G.I., Fallick, A.E., 2006. Glacial Trinity: Neoproterozoic Earth History within the British-Irish Caledonides. Geology 34, 909-912.

Meunier, A., El Albani, A., 2007. The Glauconite-Fe-Illite-Fe-Smectite Problem: A Critical Review. Terra Nova 19, 95-104.

Montanari, A., Hay, R.L., Alvarez, W., Asaro, F., Michel, H.V., Alvarez, L.W., Smit, J., 1983. Spheroids at the Cretaceous-Tertiary Boundary Are Altered Impact Droplets of Basaltic Composition. Geology 11, 668-671.

Moore, D.M., Reynolds, R.C., 1997. X-Ray Diffraction and the Identification and Analysis of Clay Minerals. Oxford University Press. 
Odin, G.S., Matter, A., 1981. Origin of Glauconites. Sedimentology 28, 611-641.

Onoue, T., Nakamura, T., Haranosono, T., Yasuda, C., 2011. Composition and Accretion Rate of Fossil Micrometeorites Recovered in Middle Triassic Deep-Sea Deposits. Geology 39, 567-570.

Porter, S.M., Knoll, A.H., 2000. Testate Amoebae in the Neoproterozoic Era: Evidence from Vase-Shaped Microfossils in the Chuar Group, Grand Canyon. Paleobiology 26, 360-385.

Porter, S.M., Meisterfeld, R., Knoll, A.H., 2003. Vase-Shaped Microfossils from the Neoproterozoic Chuar Group, Grand Canyon: A Classification Guided by Modern Testate Amoebae. Journal of Paleontology 77, 409-429.

Prave, A.R., 1999. The Neoproterozoic Dalradian Supergroup of Scotland: An Alternative Hypothesis. Geological Magazine 136, 609-617.

Prave, A.R., Fallick, A.E., Thomas, C.W., Graham, C.M., 2009. A Composite C-Isotope Profile for the Neoproterozoic Dalradian Supergroup of Scotland and Ireland. J. Geol. Soc. 166, 845857.

Rooney, A.D., Chew, D.M., Selby, D., 2011. Re-Os Geochronology of the NeoproterozoicCambrian Dalradian Supergroup of Scotland and Ireland: Implications for Neoproterozoic Stratigraphy, Glaciations and Re-Os Systematics. Precambrian Research 185, 202-214.

Sawaki, Y., Kawai, T., Shibuya, T., Tahata, M., Omori, S., Komiya, T., Yoshida, N., Hirata, T., Ohno, T., Windley, B.F., Maruyama, S., 2010. Sr-87/Sr-86 Chemostratigraphy of Neoproterozoic Dalradian Carbonates Below the Port Askaig Glaciogenic Formation, Scotland. Precambrian Research 179, 150-164.

Schumacher, R., Schmincke, H.U., 1991. Internal Structure and Occurrence of Accretionary Lapilli - a Case-Study at Laacher See Volcano. Bulletin of Volcanology 53, 612-634.

Simonson, B.M., 2003. Petrographic Criteria for Recognizing Certain Types of Impact Spherules in Well-Preserved Precambrian Successions. Astrobiology 3, 49-65.

Spencer, A.M., 1971. Late Pre-Cambrian Glaciation in Scotland. The Geological Society, London, Memoirs, 6.

Spencer, A.M., Spencer, M.O., 1972. The Late Precambrian/Lower Cambrian Bonahaven Dolomite of Islay and Its Stromatolites. Scottish Journal of Geology 8, 269-282.

Tucker, M.E., 2001. Sedimentary Petrology, 3 ed. Blackwell Publishing, Oxford.

Walker, J.D., Klepacki, D.W., Burchfiel, B.C., 1986. Late Precambrian Tectonism in the Kingston Range, Southern-California. Geology 14, 15-18.

Weaver, C.E.C.E., 1989. Clays, Muds, and Shales. Elsevier, Amsterdam; New York.

Wightman, W.G., Scott, D.B., Medioli, F.S., Gibling, M.R., 1994. Agglutinated Foraminifera and Thecamoebians from the Late Carboniferous Sydney Coalfield, Nova-Scotia - Paleoecology, Paleoenvironments and Paleogeographic Implications. Palaeogeography Palaeoclimatology Palaeoecology 106, 187-202.

\section{FIGURE CAPTIONS}

Figure 1: A: Map showing the geographic location of the Isle of Islay. B: Generalized stratigraphy of the Dalradian Supergroup and Bonahaven Formation showing spherule-bearing 
horizons. Note that the Bonahaven Formation lies stratigraphically above the Port Askaig Tillite. Adapted from Fairchild (1985); Rooney et al. (2011).

Figure 2: A: Map showing the local geology at both Caol Ila (left) and Bunnahabhain (right), arrows denote section locations. Both sections comprise strata from member 1 of the Bonahaven Formation. B: Stratigraphy of section taken $1 \mathrm{~km}$ south of Bunnahabhain showing sample locations and spherule bearing horizons. C: Stratigraphy of section taken north of Caol Ila showing sample locations and spherule bearing horizons. D: Key to lithologies.

Figure 3: Flat-bed scanned image of thin-section $485332 \mathrm{~b}$ showing spherule abundance within mudstone horizons. Section taken perpendicular to bedding. Scale bar is $10 \mathrm{~mm}$. Sample Level can be obtained from Figure 2.

Figure 4: Spherule morphologies in petrographic thin-section $30 \mu \mathrm{m}$ thickness under plane polarized light unless indicated. All scale bars are $100 \mu \mathrm{m}$. Sample levels can be obtained from Figure 2. Coordinates reported for England Finder with thin-section orientated so that fixed corner is next to thin-section label. A: photomicrograph showing spherule density within mudstone horizons, 485332 U41/0. B: photomicrograph of two spherules ( $m$ and $n$ ) overlapping. The nearest (n) shows a flat edge (arrow) and a central line of dark material likely composed of graphite and pyrite, PB-I8 G39/2. C: photomicrograph of spherule with flat edge (arrow) 485332 K37/1. D: photomicrograph of spherule with flat edge (p) showing mudstone (q) draping around spherule, 485332 with coordinates $(39.3,188,3)$ on microscope where Z36 is $(39.4,116.1)$. E: photomicrograph showing two spherules with tapering necks (arrows), $485332 \mathrm{M} 41 / 1$. F: photomicrograph showing the same two spherules as E under cross-polarized light emphasizing the broad orientation of crystallites perpendicular to wallsir radial fabric, $485332 \mathrm{M} 41 / 1$. G: photomicrograph of two spherules both with neck like structures including spherule with indentation (right), PB-I11B R30. H: photomicrograph of conjoined spherules, 485332 L47/3.

Figure 5: Histograms of size distribution of spherules. Top: Distribution based on measured maximum diameters from petrographic thin-section. Bottom: Corrected distribution using the method of Hennig and Elias (1971) and assumptions/coefficients of Fairchild (1977) to account for cut effects in petrographic thin-section. Size classes were chosen to accommodate the correction method.

Figure 6: XRD representative scan of less than $2 \mu \mathrm{m}$ fractions extracted from bulk composition

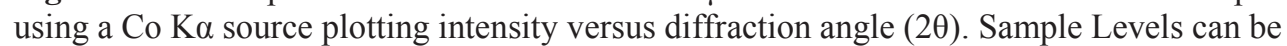
obtained from Figure 2. A: BD004. B: BD008. C: BD014. D: CID008. Black dots represent peaks associated with kaolin-group minerals. All other peaks associated with micas. Each scan shows clear $h k l$ peaks belonging to muscovite of the $2 \mathrm{M} 1$ polytype.

Figure 7: Chart depicting the multiple lines of evidence upon which each physical mode of origination for the spherules was rejection (based on defining characteristics of physical phenomena from Bucher and Grapes, 2011; Callegari and Pertsev, 2007; Cruz and Galan, 2002; Dressler and Reimold, 2001; Glass and Simonson, 2012; Grieve, 1991; Kirkham, 2003; Montanari et al., 1983; Onoue et al., 2011; Schumacher and Schmincke, 1991; Simonson, 2003; Tucker, 2001). The lines of evidence are separated into three distinct categories: distributional, morphological, and mineralogical. 
Figure 8: Results of morphological two-dimensional shape comparison showing similarities between unambiguous VSMs and the Bonahaven spherules. The number of individuals counted in each case is given as $n$.

Figure 9: Photomicrographs of unambiguous VSMs, Bonahaven Spherules, and modern analogues for comparison. All scale bars represent $50 \mu \mathrm{m}$. Sample levels can be obtained from Figure 2. Where coordinates reported, they are England Finder coordinates with thin-section orientated so that fixed corner is next to thin-section label. A: VSMs attached at the aperture suggested reproductive stage (Porter et al., 2003). B: Bonahaven conjoined spherules showing similarities to A, 485332 L47/3. C: VSM from the Draken Formation preserved as silica-filled internal mould in dolomite (Knoll et al., 1991). D: Bonahaven spherule showing similar aperture to $\mathrm{C}, 485332$ with coordinates $(39.3,188.3)$ on microscope where Z36 is $(39.4,116.1)$. E: VSM from Upper Walcott population (Porter and Knoll, 2000). F: Modern Hyalosphenia papilio with organic test (courtesy of Lahr).

Figure 10: Stages of proposed origination from Neoproterozoic testate organism to VSM preserved within siliciclastic sediments of the Bonahaven Formation. 
B

$25.5 \mathrm{~km}$

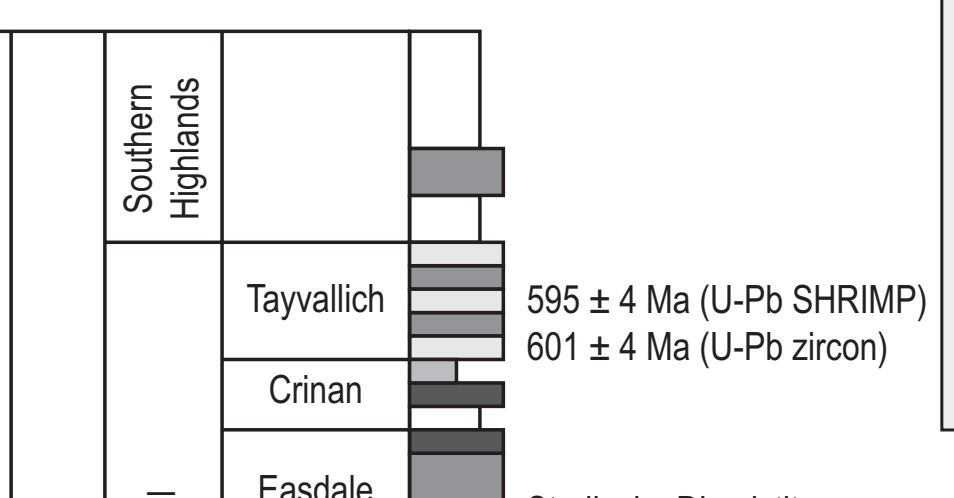

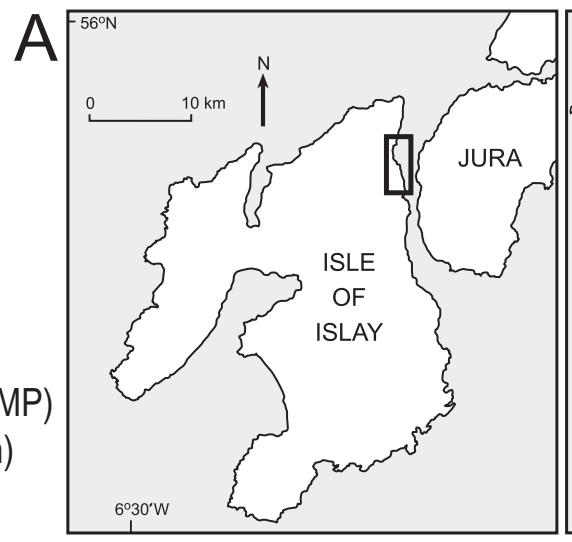

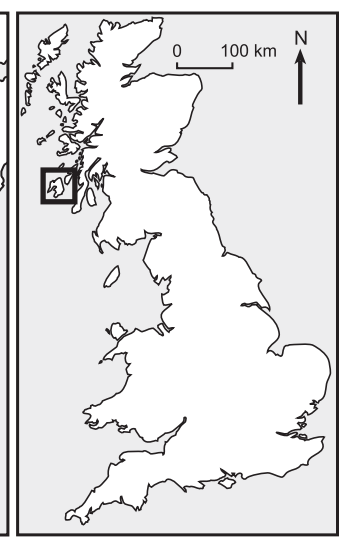

$300 \mathrm{~m}$

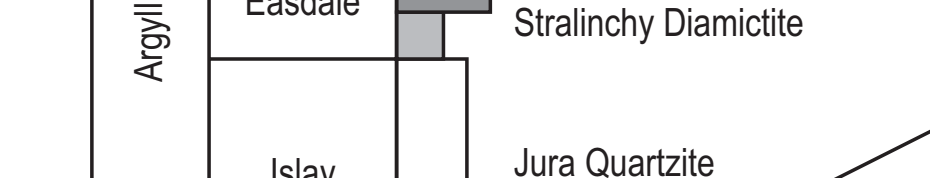

lay

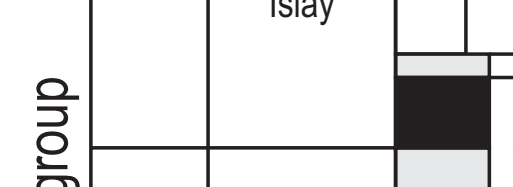

Port Askaig

Tillite

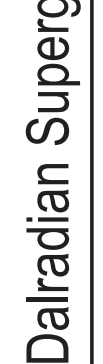

Bar $A$

Blair Atholl

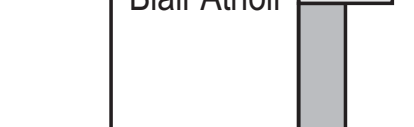

들

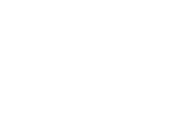

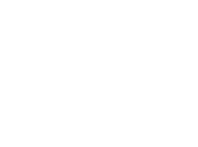

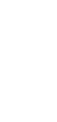

$659 \pm 9 \mathrm{Ma}$ (Re-Os)

Ballachulish
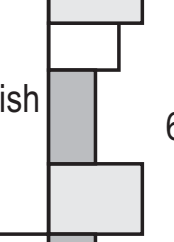

aber

Lochaber

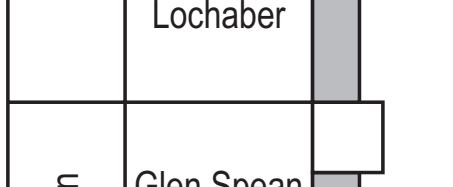

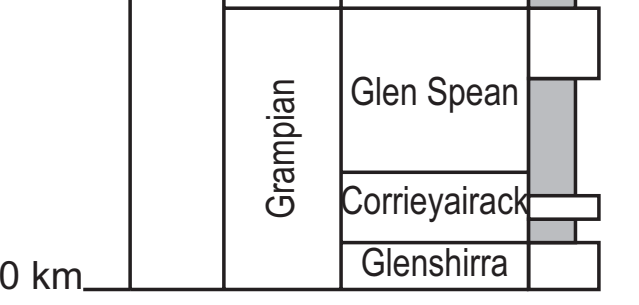

$------$

$806 \pm 3 \mathrm{Ma}$ (U-Pb monazite)
Silty sandstons and mudstones (slates phyllites) with a central pure dolostone

Dolomitic sandstones, siltstones and mudstones (slates), and pure dolostones including stromatolites

$0 \mathrm{~m}$

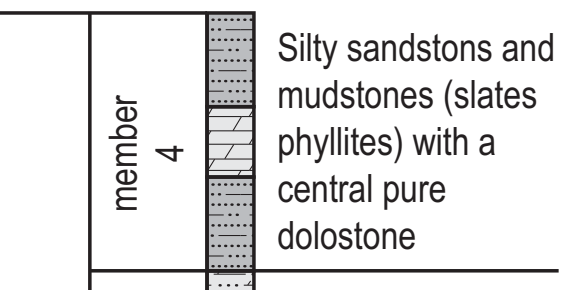

C

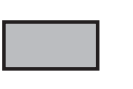

Finer Grained Siliciclastics

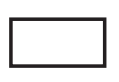

Coarser Grained

Siliciclastics

Carbonate

Glacial Diamictite
Basic Volcanics

Conglomerate
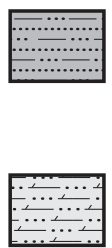

Interbedded sandstones, siltstones, and mud-

Pure dolostone stones

Interbedded dolomitic

sandstones, siltstones, and mudstones

Quartzite 


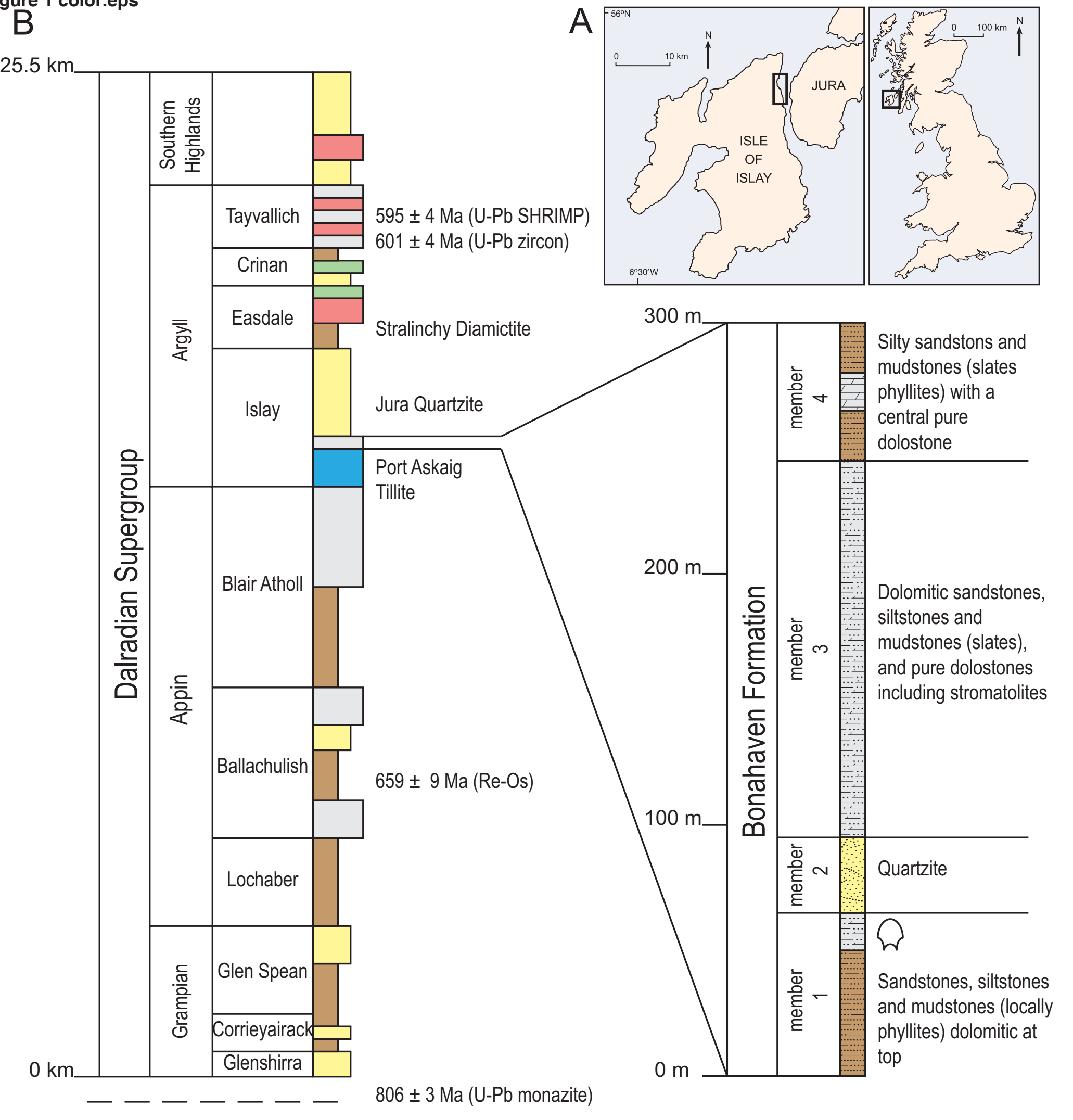

\section{C}

\section{Finer Grained Siliciclastics}

$\square$ Coarser Grained Siliciclastics

Carbonate

Glacial Diamictite
A

Silty sandstons and mudstones (slates phyllites) with a central pure dolostone

Dolomitic sandstones, siltstones and mudstones (slates), and pure dolostones including stromatolites

Sandstones, siltstones and mudstones (locally phyllites) dolomitic at top
Basic Volcanics

Conglomerate

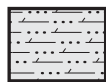

Interbedded dolomitic sandstones, siltstones, and mudstones siltstones, and mudstones

Quartzite
Pure dolostone

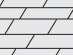

Pure dolostone

Spherules present 


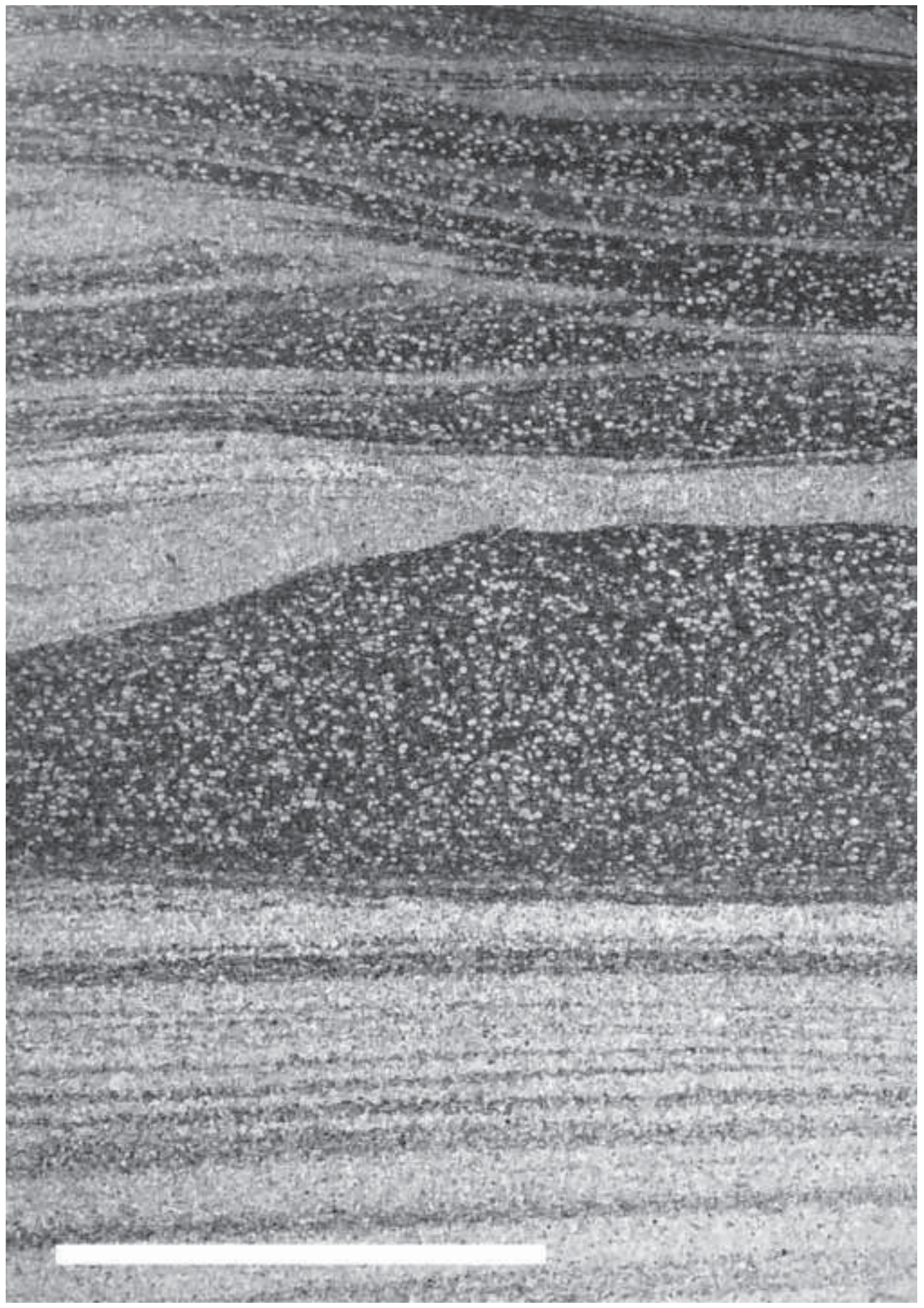




\section{Figure 3 color.tif}

Click here to download high resolution image

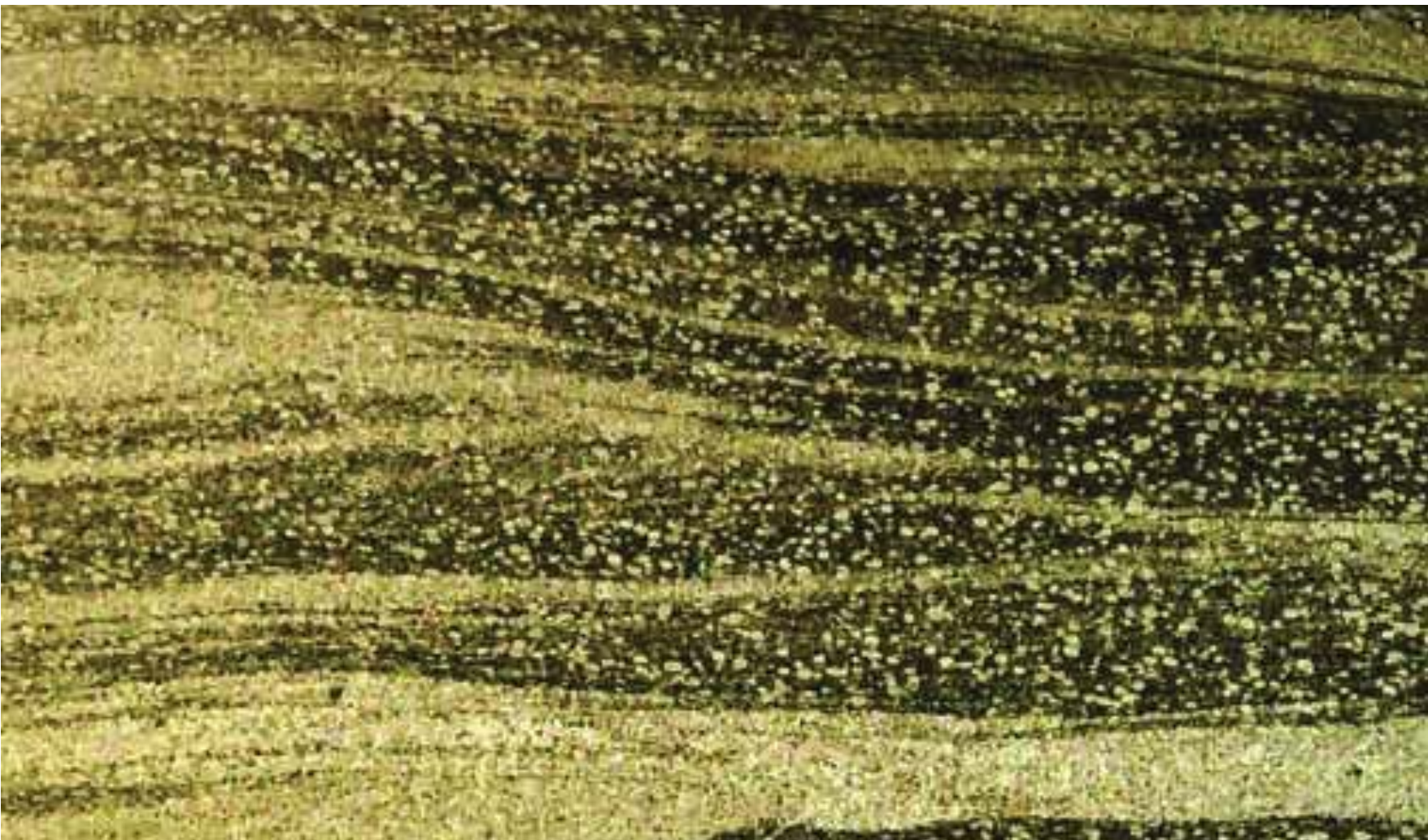

39. 1. 3 :

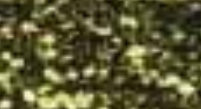

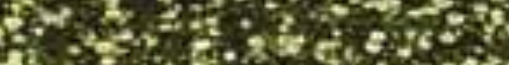

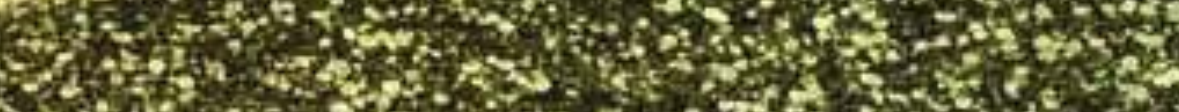

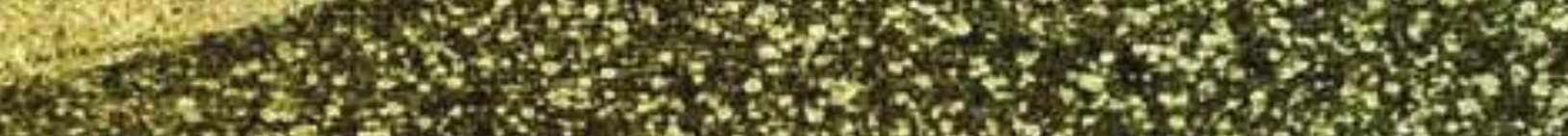

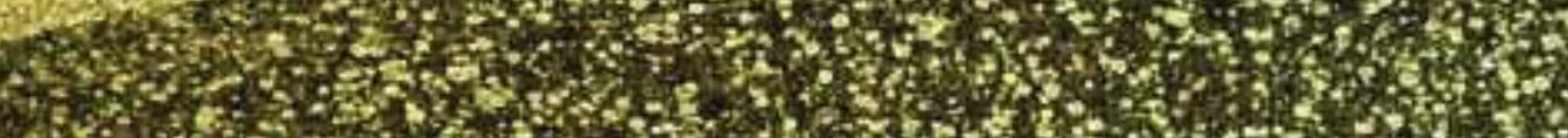

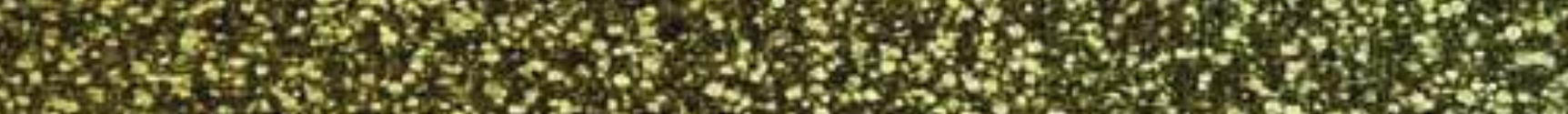

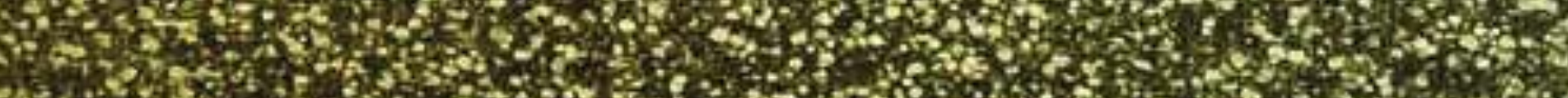
S.

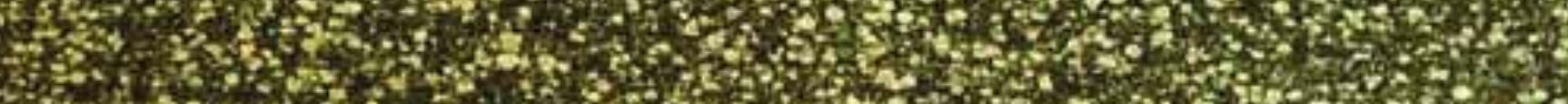

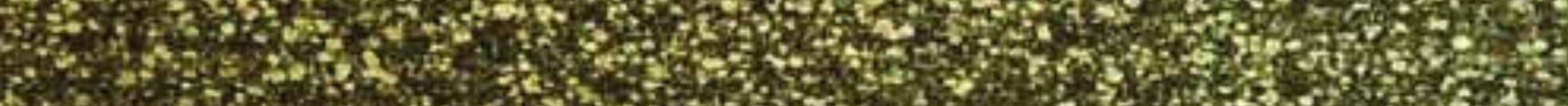

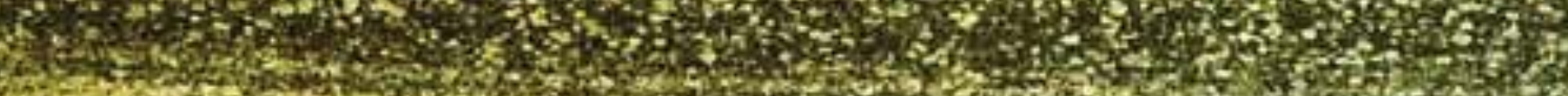

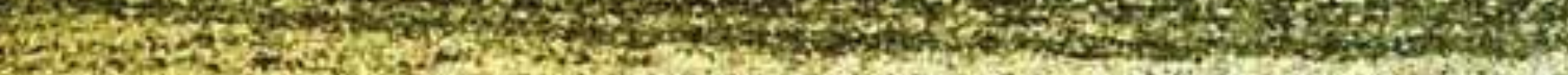

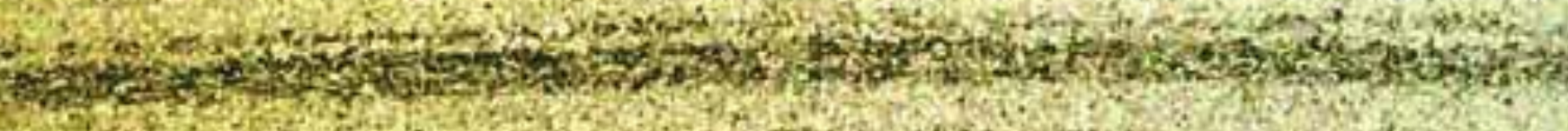

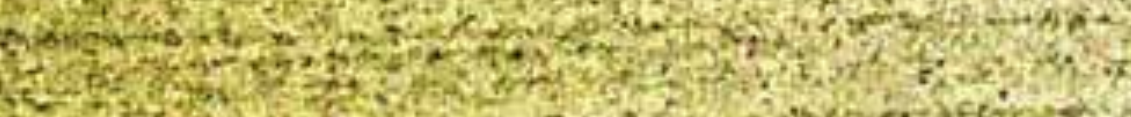

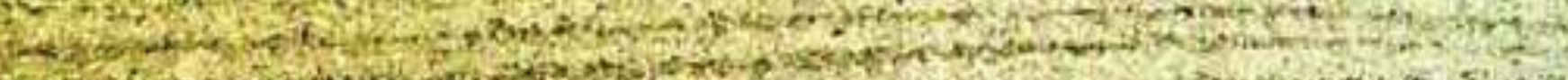

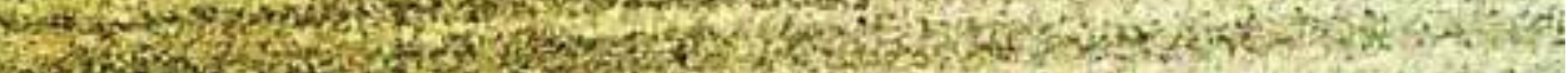
7.

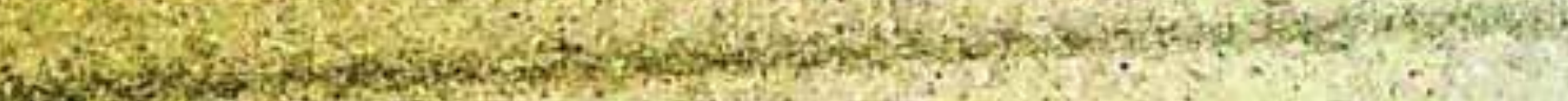
ar

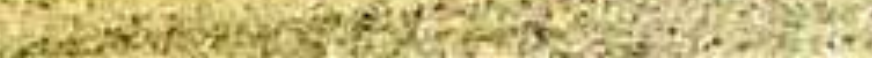


Figure 4 bw.tif

Click here to download high resolution image
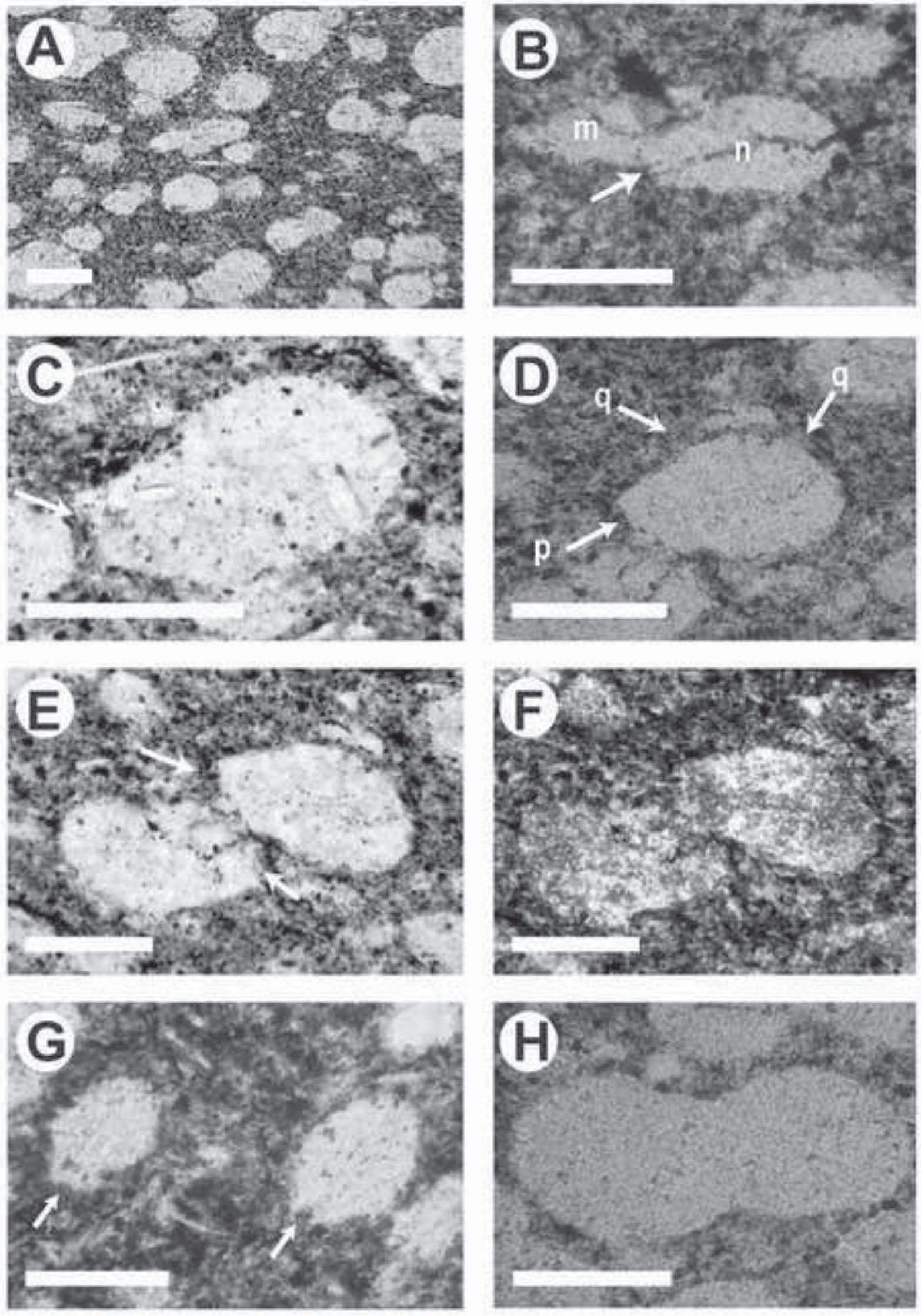

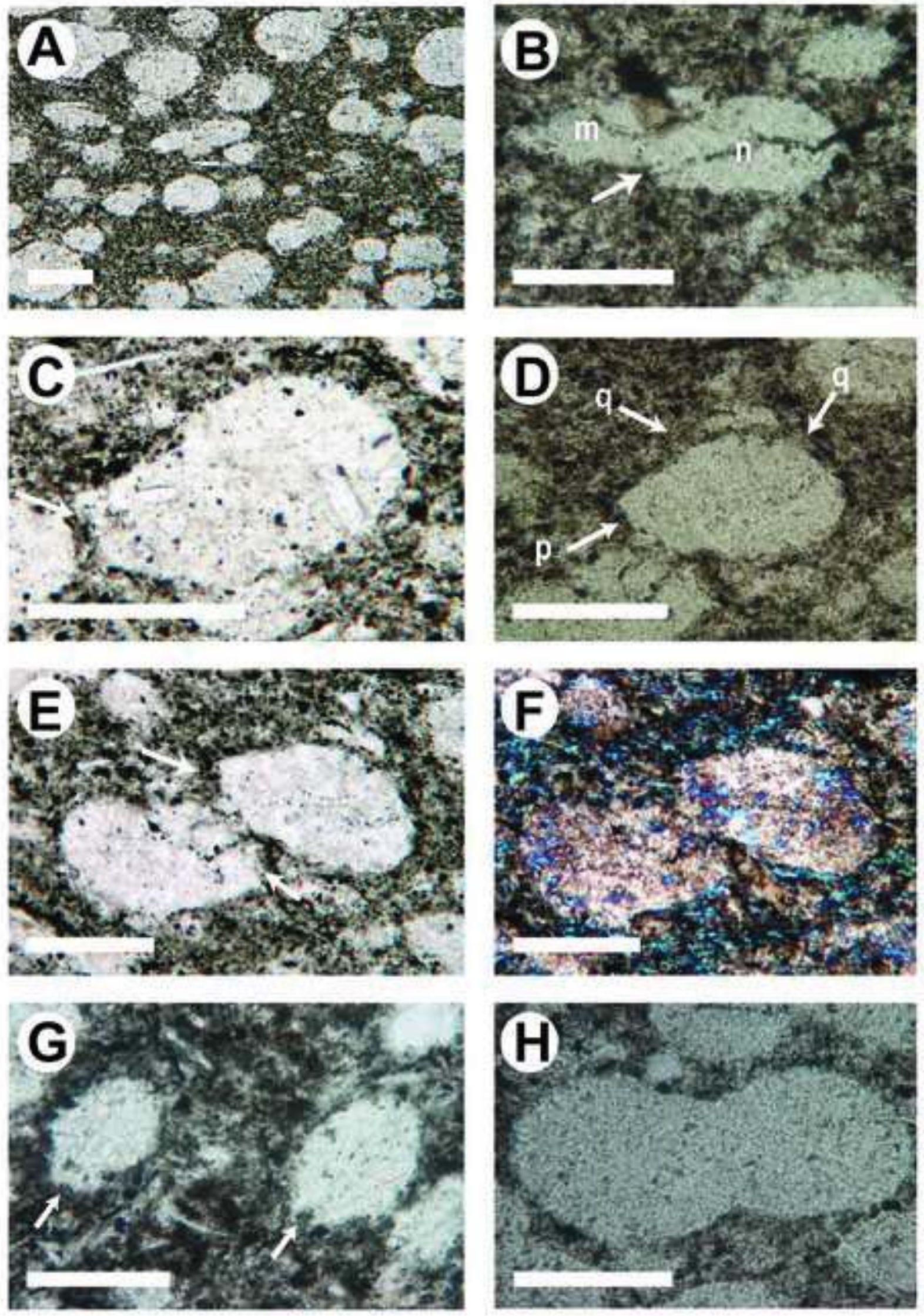

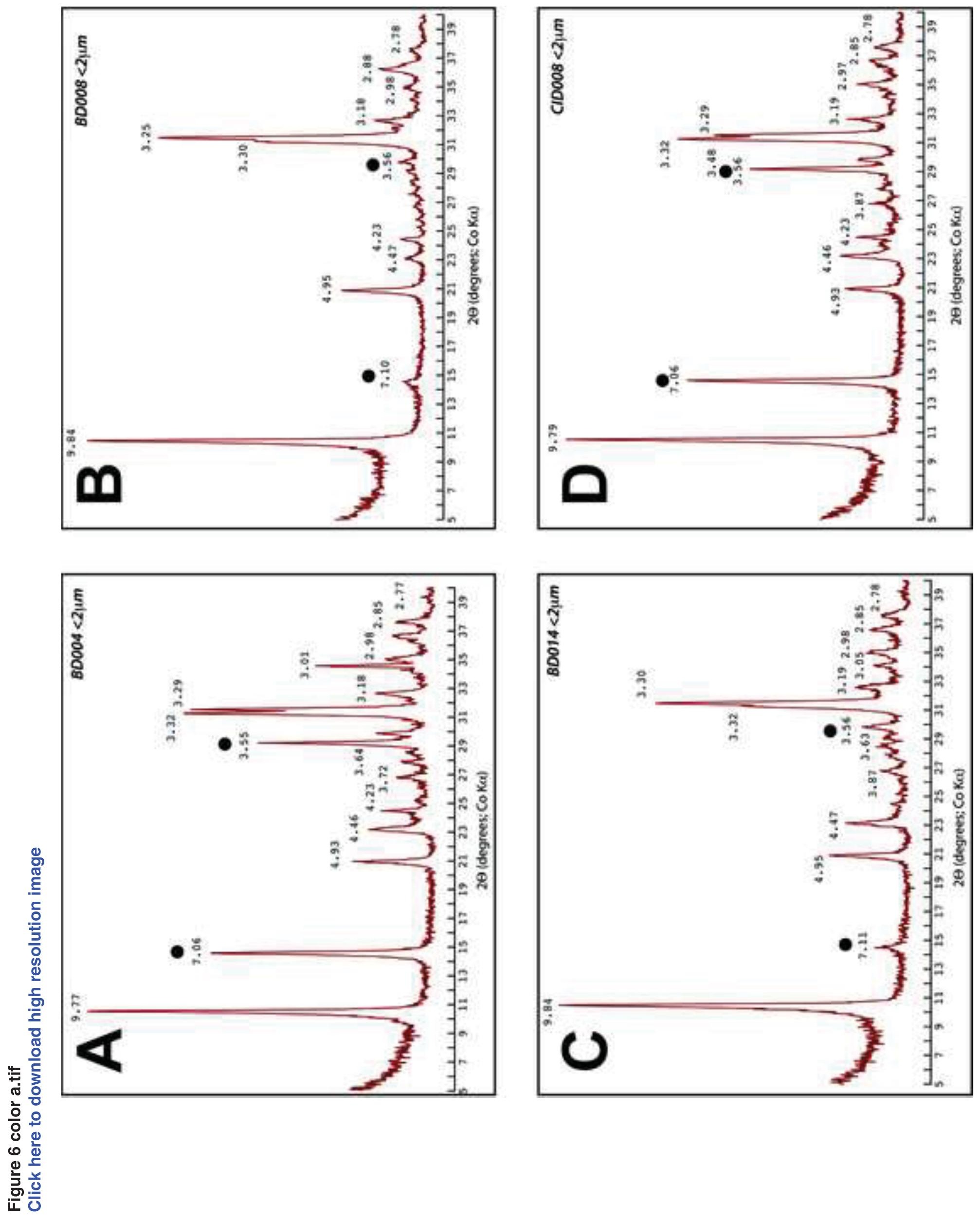


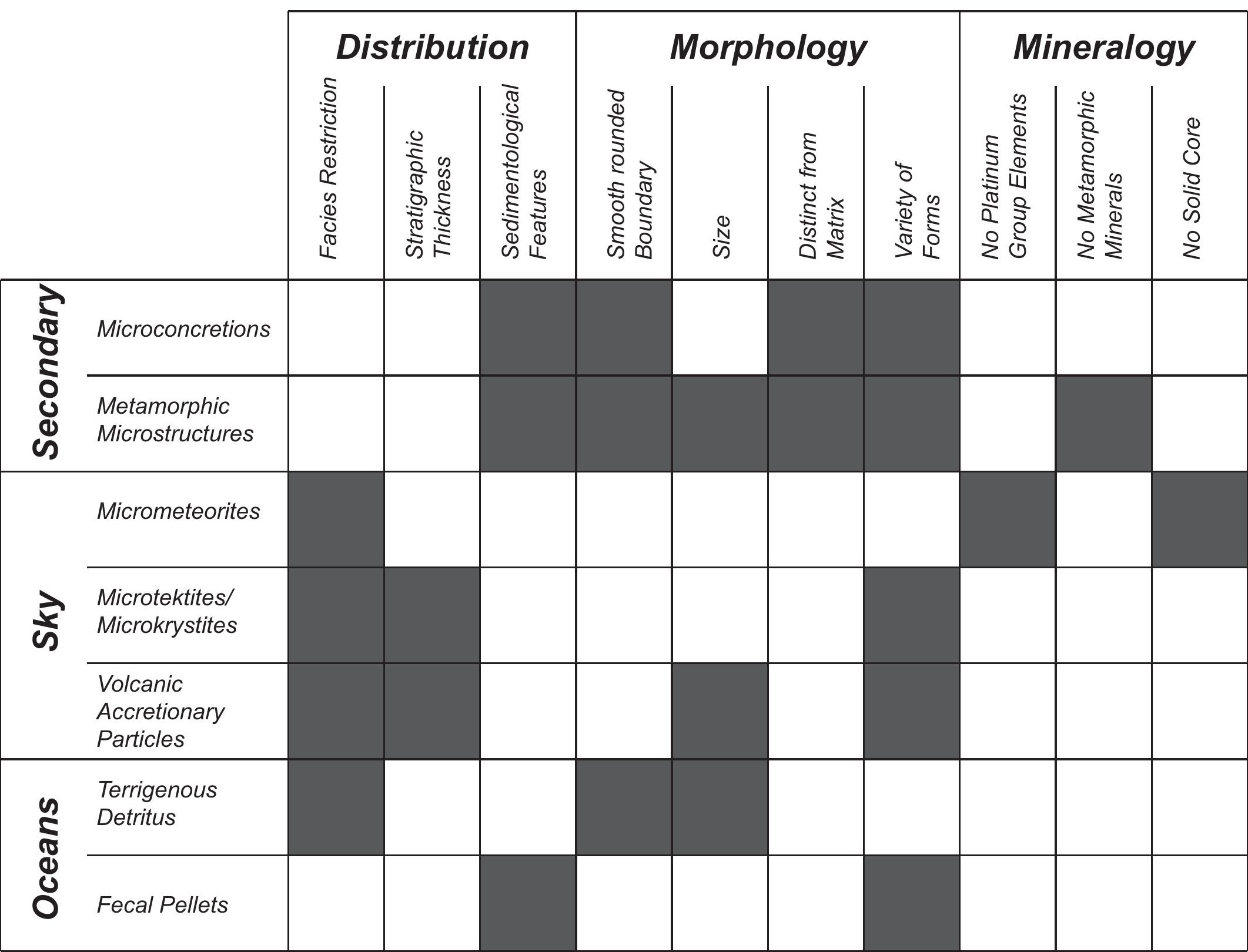




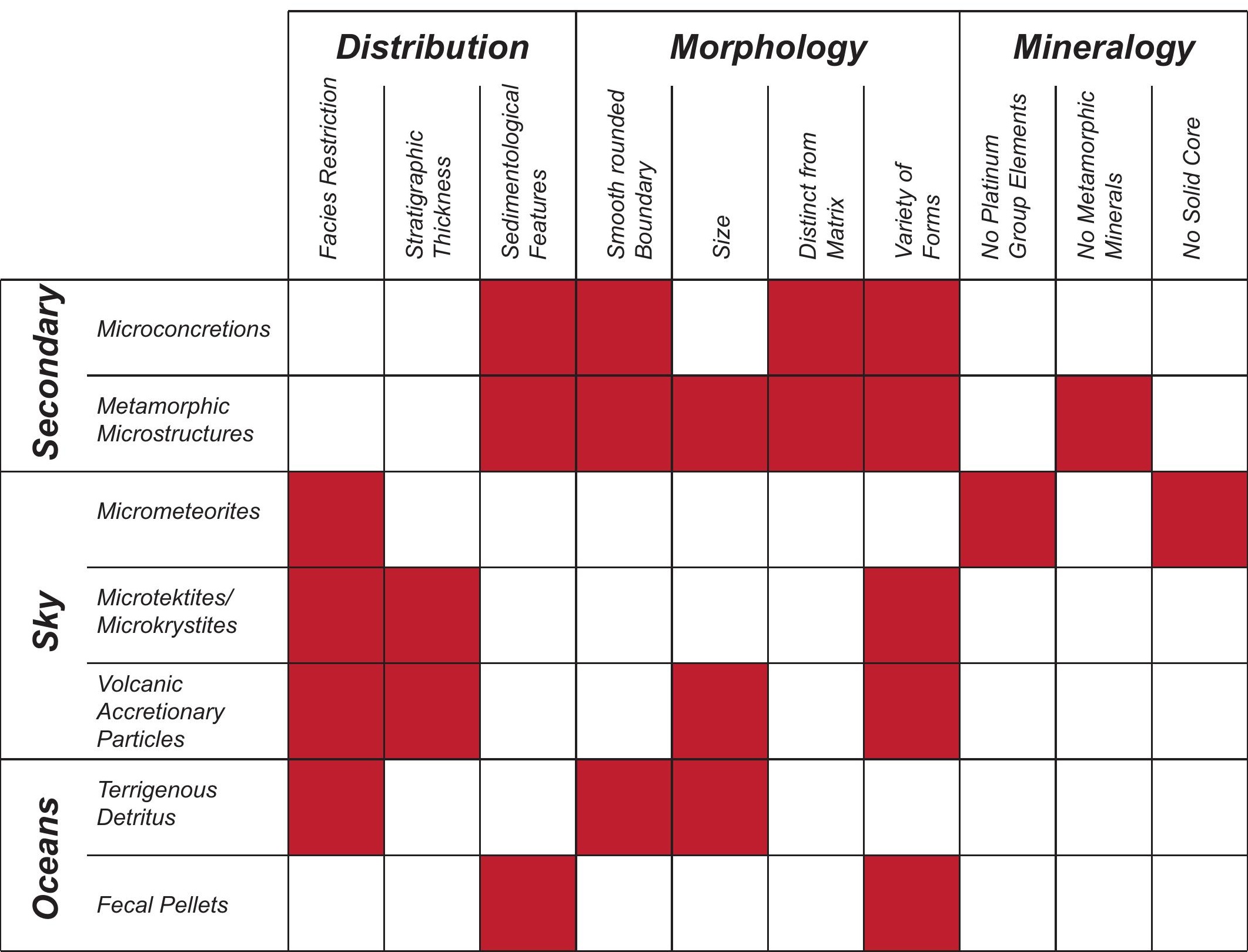



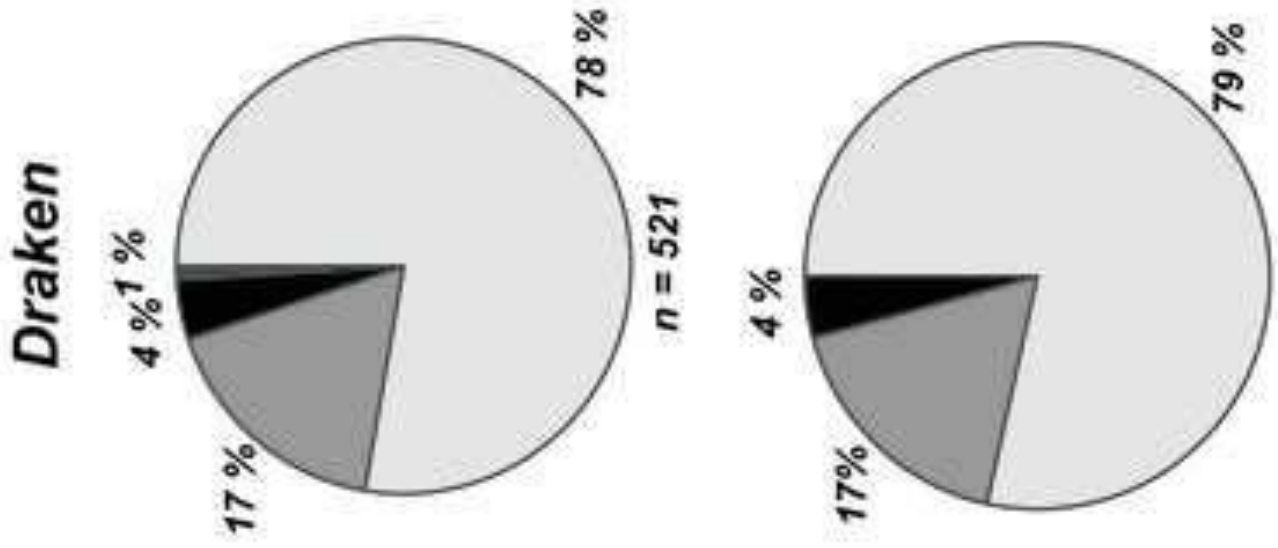

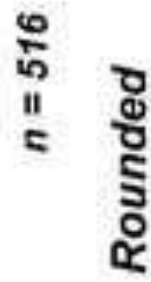
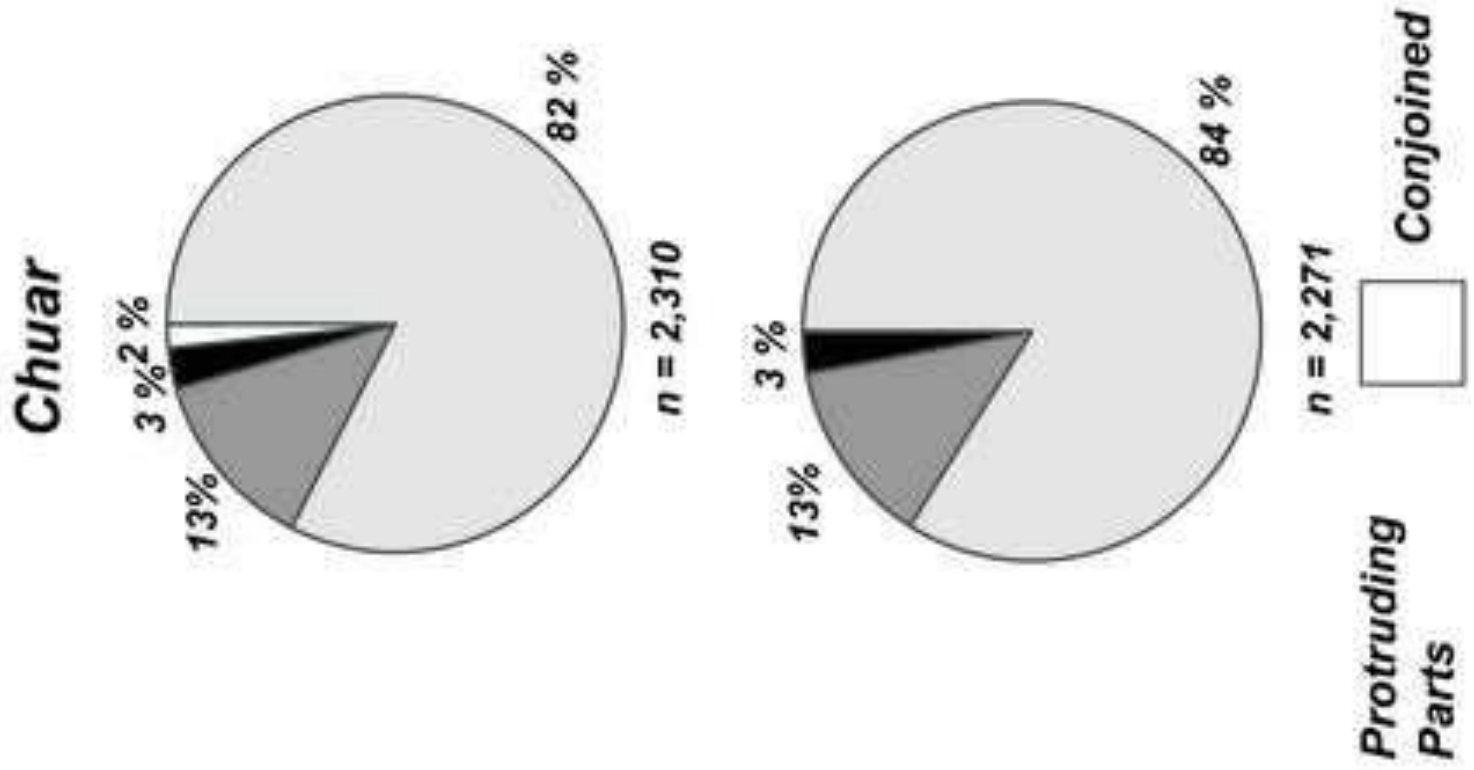

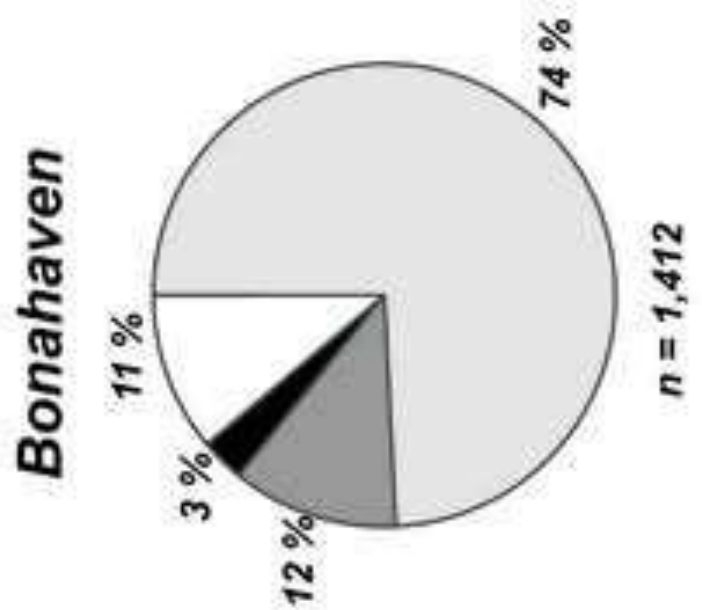

рәицогио бu!pnןou

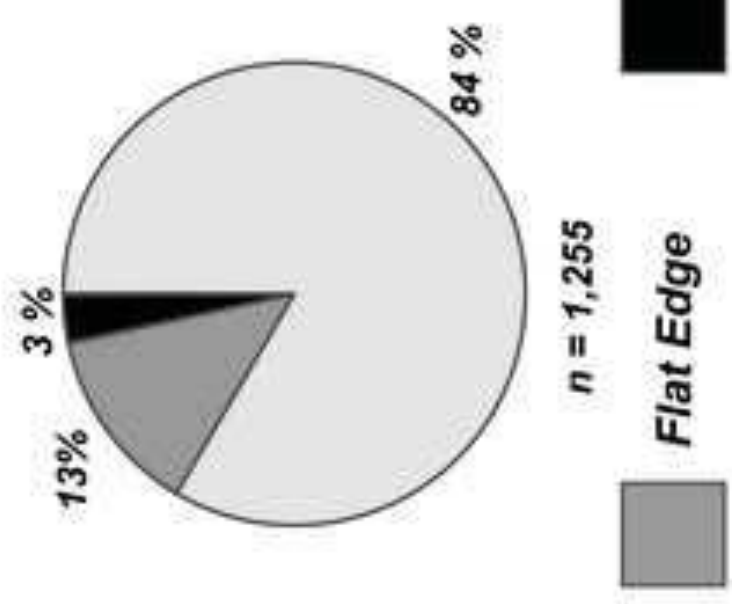

рәи!о!uos

6u!pnןอx 

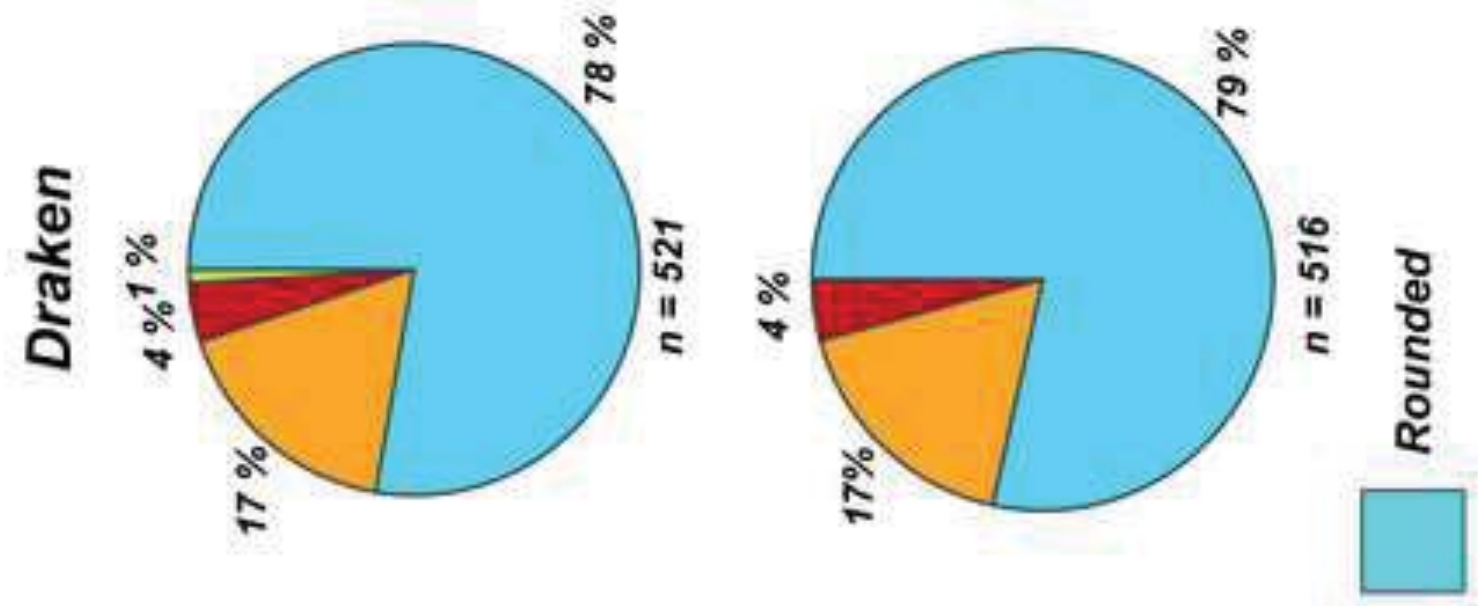

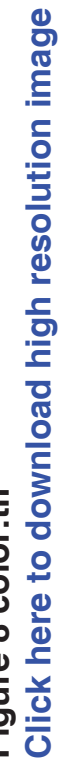
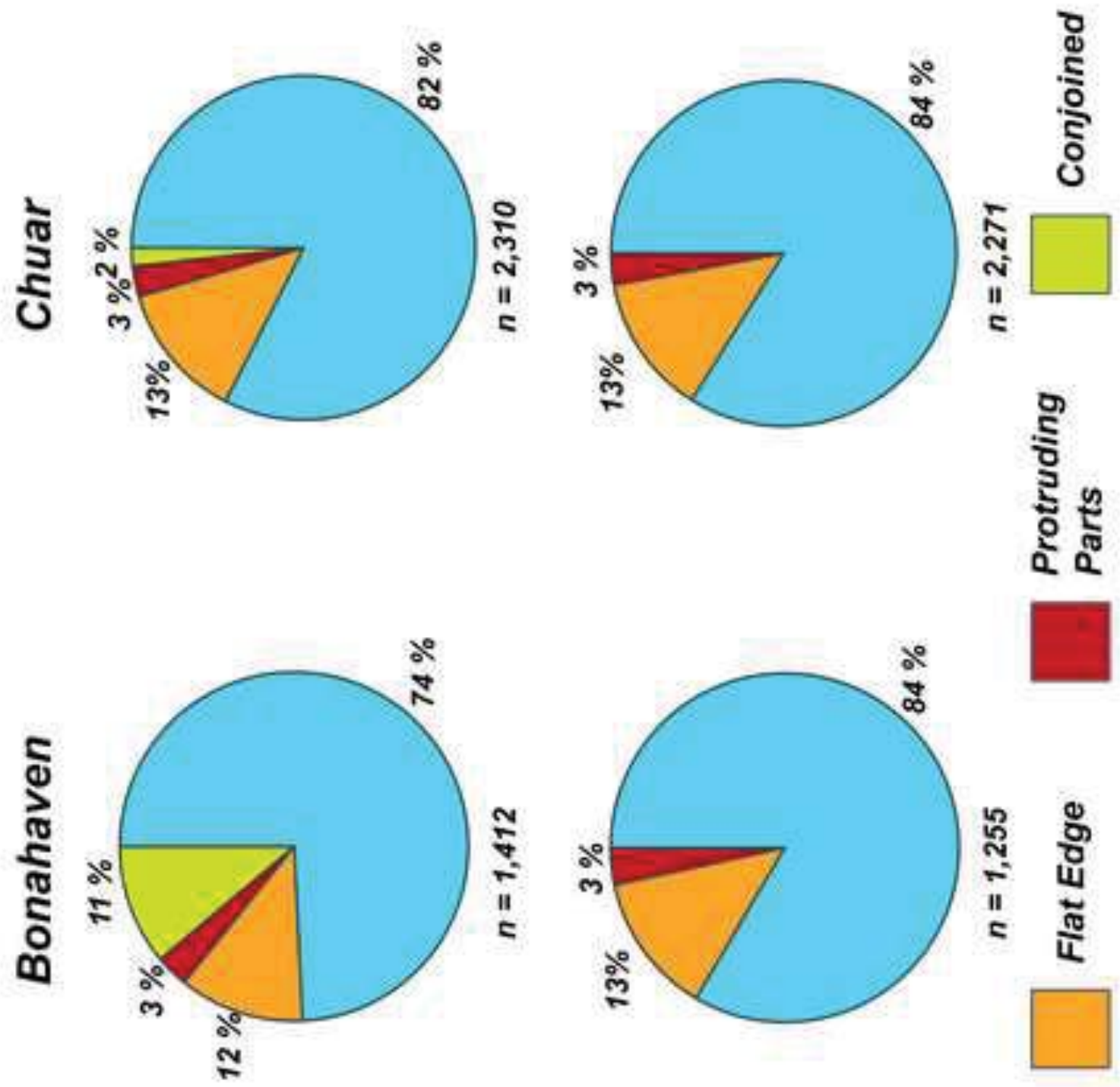

рәи!оाио 6u!pnןэu

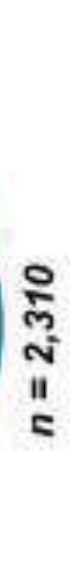

$\frac{1}{8}$

рәи!оиoว

6и!pnןอ× 

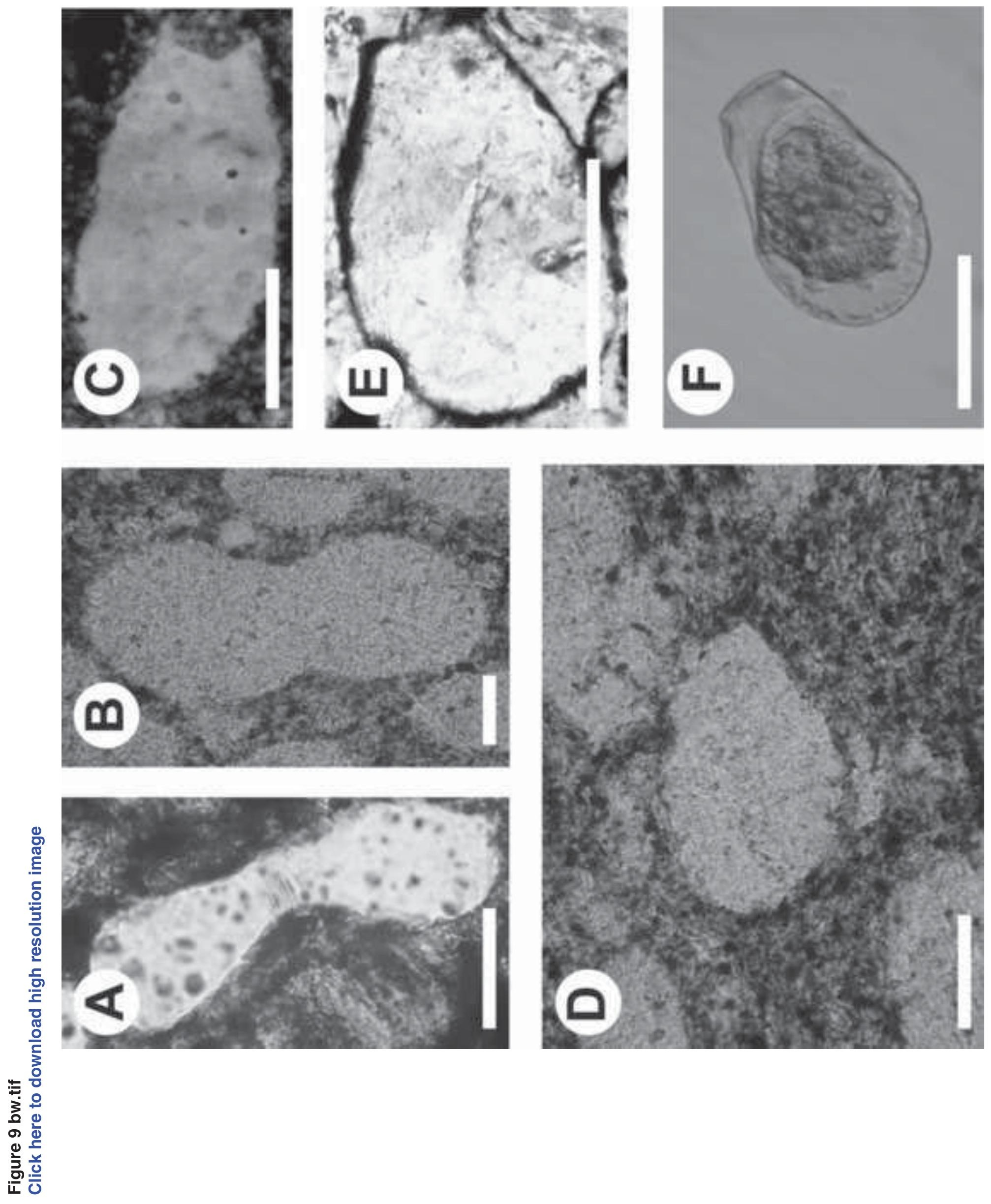

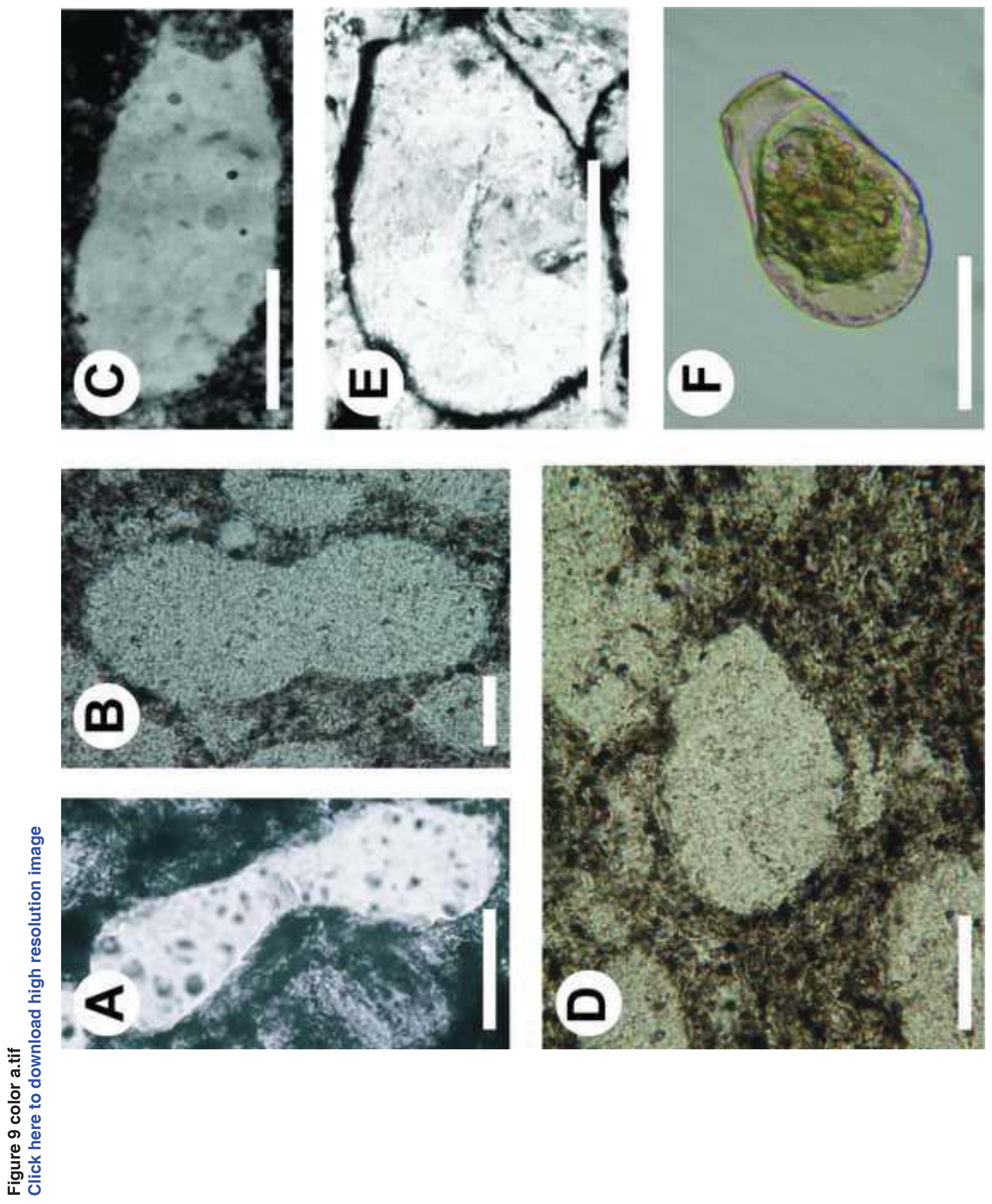
1

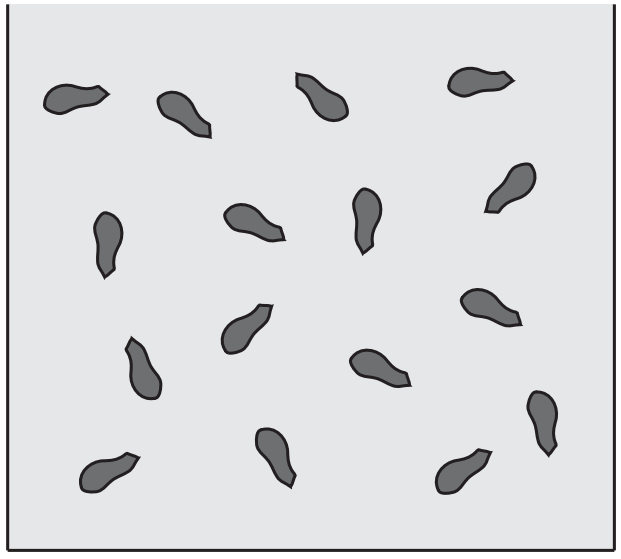

Testate organisms in local environment.
4

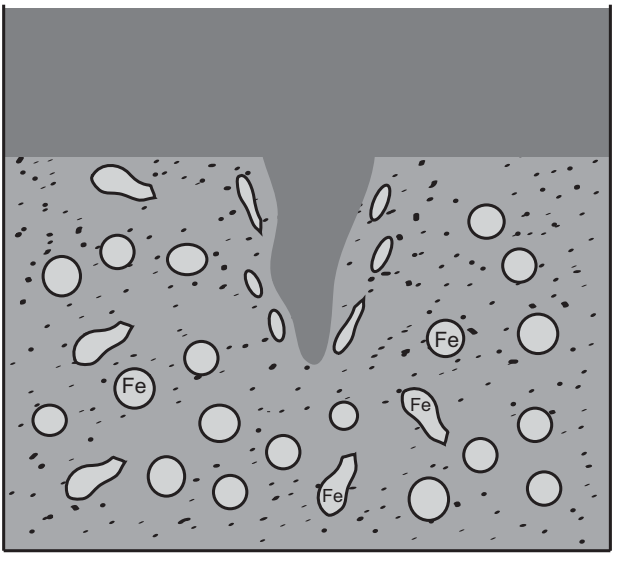

Penecontemporaneous in-filling of tests with iron-rich mineral precurser and deposition of coarser sands.
2

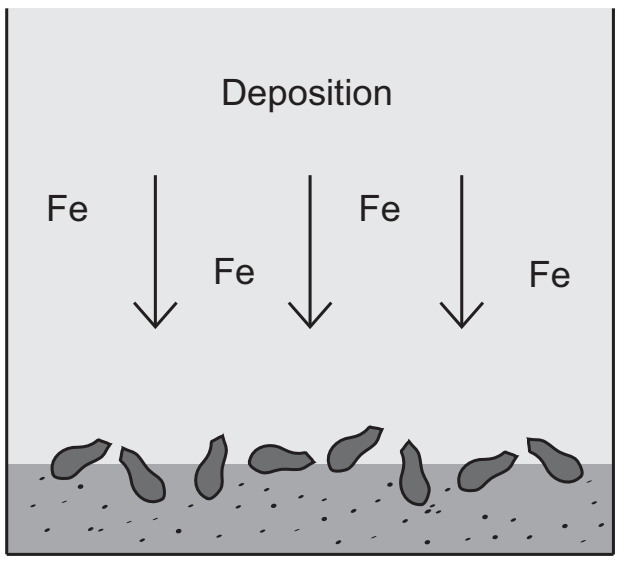

Deposition of dead organisms with muds from suspension. Note possible ferruginous Neoproterozoic waters.

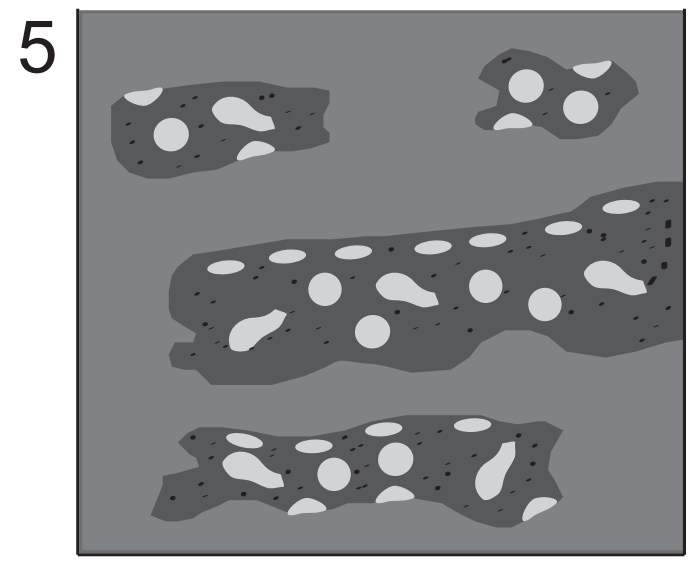

Erosion to form intraclast of mud.
3

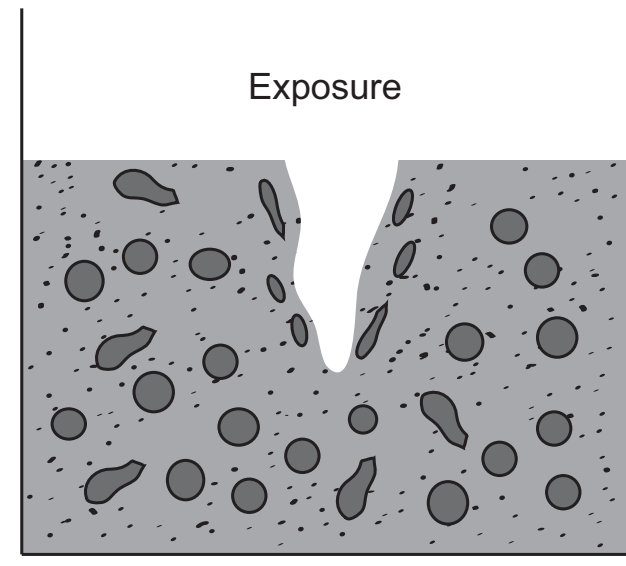

Sub-aerial exposure leads to desiccation and compaction with spherules flattening parallel to desiccated margin.

6

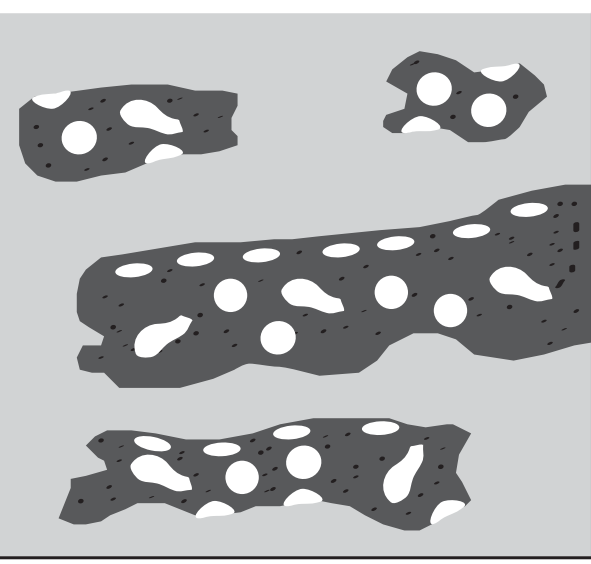

Subsequent metamorphism as denoted by change in color. 


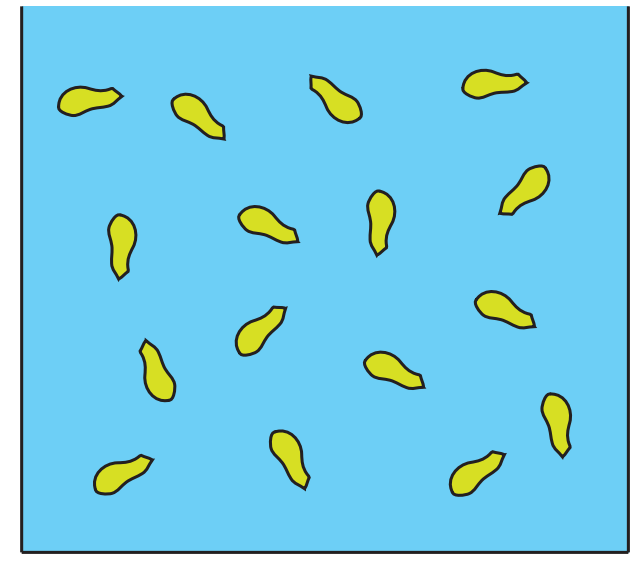

Testate organisms in local environment.

4

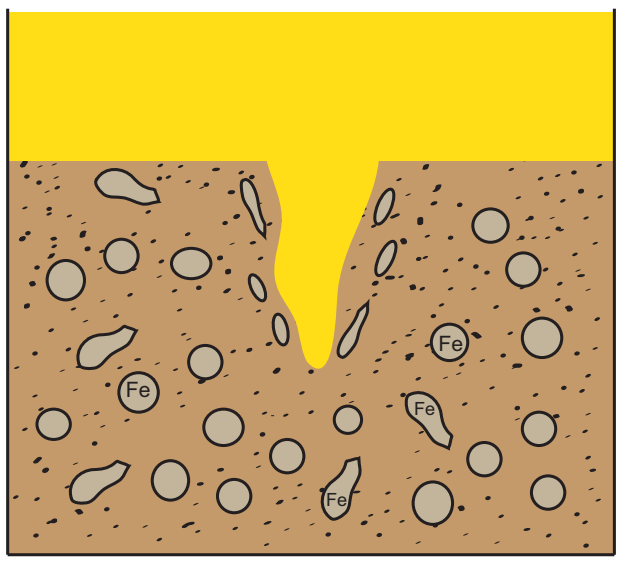

Penecontemporaneous in-filling of tests with iron-rich mineral precurser and deposition of coarser sands.
2

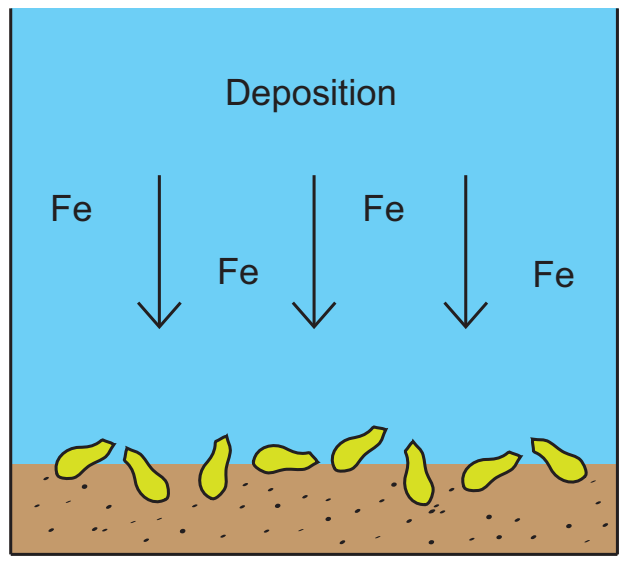

Deposition of dead organisms with muds from suspension. Note possible ferruginous Neoproterozoic waters.

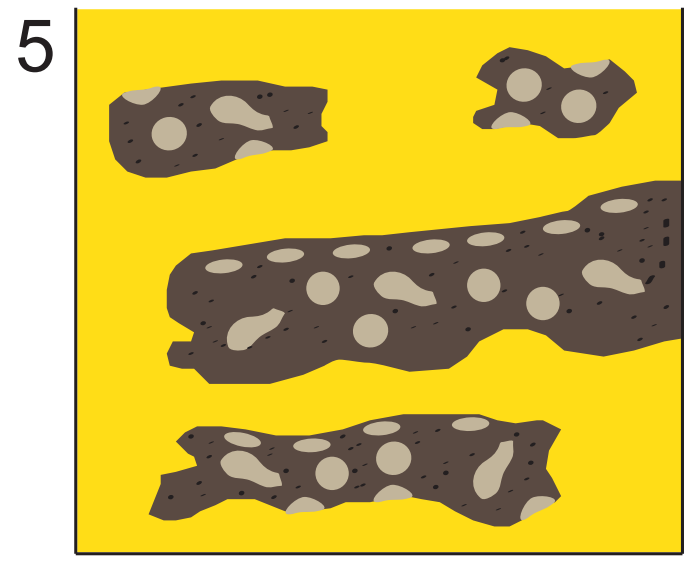

Erosion to form intraclast of mud.
3

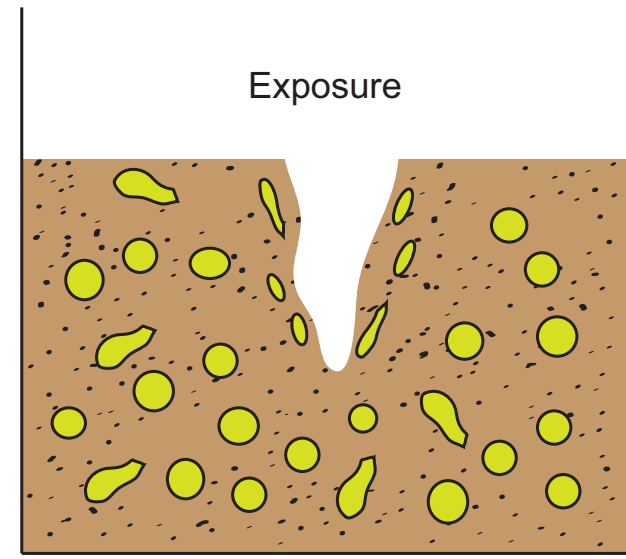

Sub-aerial exposure leads to desiccation and compaction with spherules flattening parallel to desiccated margin.

6

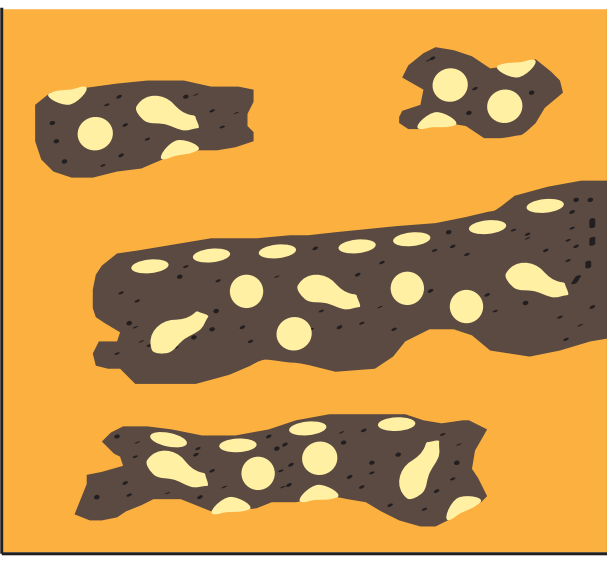

Subsequent metamorphism as denoted by change in color. 